\title{
5. LONG-RANGE TRANSPORT OF ICELANDIC TEPHRA TO THE IRMINGER BASIN, SITE 9191
}

\author{
Christian Lacasse, ${ }^{2}$ Reinhard Werner, ${ }^{3}$ Martine Paterne, ${ }^{4}$ Haraldur Sigurdsson, ${ }^{2}$ Steven Carey, ${ }^{2}$ and Guy Pinte ${ }^{5}$
}

\begin{abstract}
The 147-m-long sediment sequence recovered from Ocean Drilling Program Leg 152 Site 919 in the Irminger Basin contains several well-preserved volcanic ash layers and ash zones that provide a record of long-range transport of tephra from Iceland toward Greenland during the Pliocene-Pleistocene. A total of eight tephra layers and ash pods as well as three ash zones recovered in two separate holes (919A and 919B) were analyzed for major and trace element chemistry and grain size. Relative ages of the tephra layers were estimated based on oxygen isotope stratigraphy and correlation with other chronostratigraphic markers present in North Atlantic sediments and ice cores in Greenland. Based on their sorting coefficient and grain size, it is inferred that discrete ash layers between 1 and $5 \mathrm{~cm}$ thick are the result of ash fallout from large explosive eruptions. The tephra are bimodal (colorless/rhyolitic and sideromelane-tachylite/basaltic glass) or basaltic in composition, with crystal content between less than $15 \%$ for the discrete layers to more than $50 \%$ for the ash zones. The major element composition of glasses indicates two compositional groups: basaltic and rhyolitic. All of the tephra layers have an affinity with either a tholeiitic or an alkalic source in Iceland. Two separate mixed tephra layers, occurring between 10 and $11 \mathrm{~m}$ below seafloor at Site 919 , were found to correlate with the ice-rafted ash Zone 2, based on their rhyolitic glass chemistry. Ash Zone 2 is a chronostratigraphic marker dated at about 55-57 ka in marine sediment and at about $52 \mathrm{ka}$ in a Greenland ice core. The rhyolitic mixed tephra are interpreted to have been erupted during two large explosive eruptions of Tindfjallajökull volcano in southern Iceland, at a few hundred years interval.

From the current pattern of seasonal variation in the atmospheric circulation over Iceland, it is suggested that the tephra were likely transported by easterly winds occurring at about $30 \mathrm{~km}$ elevation in midsummer, followed by fallout in southern Greenland and in the Irminger Basin.
\end{abstract}

\section{INTRODUCTION}

A total sediment sequence of $147 \mathrm{~m}$ was cored in the Irminger Basin at Site 919 , in three drill holes $\left(62^{\circ} 40.20^{\prime} \mathrm{N}, 37^{\circ} 27.61^{\prime} \mathrm{W} ; 2088 \mathrm{~m}\right.$ water depth; Fig. 1). Quaternary sediments of Site 919 were found to be the only sediments recovered during Leg 152 that preserved discrete ash layers. The scarcity of ash layers is likely to be a result of the great distance from Iceland, which is approximately $750 \mathrm{~km}$ to the east-northeast. Magnetobiostratigraphic data indicate a minimum sedimentation rate for Holes 919A and 919B of about $12 \mathrm{~cm} / \mathrm{k} . \mathrm{y}$. with the Brunhes/Matuyama boundary located at about $120 \mathrm{~m}$ below seafloor (mbsf), dating the entire sequence of Pliocene-Pleistocene age. This study focuses on the Pliocene-Pleistocene tephra layers recovered from Cores 152-919A-1H through $10 \mathrm{H}$, and from Cores $152-$ 919B-1H through $8 \mathrm{H}$, with the sequence in Hole 919B drilled between 18.7 and 90.0 mbsf. Continuous advanced piston corer (APC) coring from the top to the bottom of the Hole 919A sequence was completed with a total recovery of $100 \%$. Such excellent recovery allowed an age model to be constructed, based on the $\delta^{18} \mathrm{O}$ of planktonic foraminifers, in spite of limited sampling resolution (Flower, this volume). Among all the records from Deep Sea Drilling Project (DSDP) and Ocean Drilling Program (ODP) and current piston coring, drilling at Site 919 was by far the longest recovered in the Irminger Basin, providing new information on the marine sedimentation of volcanic ash as well as ice-rafted debris for approximately the last 800 k.y., a period characterized by full-scale glacial-interglacial oscillations. Based on the high accumulation/resolution record of Site 919 and its proximity to Greenland, the recovery and study of volcanic ash layers present in this sequence are of particular interest for the

${ }^{1}$ Saunders, A.D., Larsen, H.C., and Wise, S.W., Jr. (Eds.), 1998. Proc. ODP, Sci. Results, 152: College Station, TX (Ocean Drilling Program).

${ }^{2}$ Graduate School of Oceanography, University of Rhode Island, Narragansett, RI 02882, U.S.A. Lacasse: lacasse@gsosun1.gso.uri.edu

${ }^{3}$ GEOMAR, Wischhofstrasse, D-2300 Kiel 14, Federal Republic of Germany.

${ }^{4}$ Centre des Faibles Radioactivités, Gif-sur-Yvette, France. France. purpose of correlating them with atmospheric records (i.e., ice cores) on Greenland. We performed analyses on six discrete tephra layers and two ash zones in addition to four ash pods, which were located based on shipboard description (Shipboard Scientific Party, 1994a). Electron microprobe analysis of volcanic glass shards and instrumental neutron activation analysis (INAA) of bulk ash layers were used to infer potential sources. Based on their grain-size characteristics and their distance from the source, an attempt is made to interpret the mode of transport and deposition of the discrete tephra layers.

\section{PALEOENVIRONMENT AND SEDIMENTATION IN THE IRMINGER BASIN}

Initiation and formation of the Irminger Basin resulted from subsidence and deepening of the seafloor between East Greenland and the Reykjanes Ridge from the early Eocene (Larsen, 1990). The sedimentary environment evolved progressively from shallow shelf conditions (early and middle Eocene) to deep marine conditions (late Oligocene to present). Oceanic surface circulation in the basin is dominated at present by a counterclockwise gyre represented by the Irminger Current and the East Greenland Current flowing southward along the East Greenland coast (Johannessen, 1986). Paleoceanographic reconstruction during the Last Glacial Maximum (LGM) at $18 \mathrm{ka}$, indicates, however, that this current system was weakened as a result of a southward shift of the polar front and sea ice cover (Kellogg, 1980).

Late Quaternary sedimentation in the Irminger Basin was particularly sensitive to climate fluctuations, with the repeated advance and retreat of the polar front as well as continental ice (Ruddiman and McIntyre, 1973; Kellogg, 1975; Ruddiman and McIntyre, 1976). Deposition of carbonate ooze (interglacial periods) alternated with glacio-marine deposits (glacial periods). This lithologic succession characterizes the central part of the Basin, which was not influenced by terrigenous inputs from either the Greenland or Iceland shelves, or indeed from the aseismic ridge connecting the two (e.g., core SU9029 in Lacasse et al., 1996).

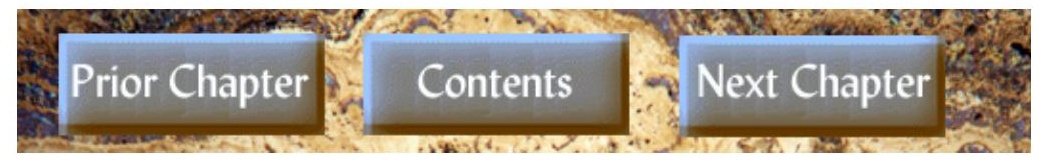




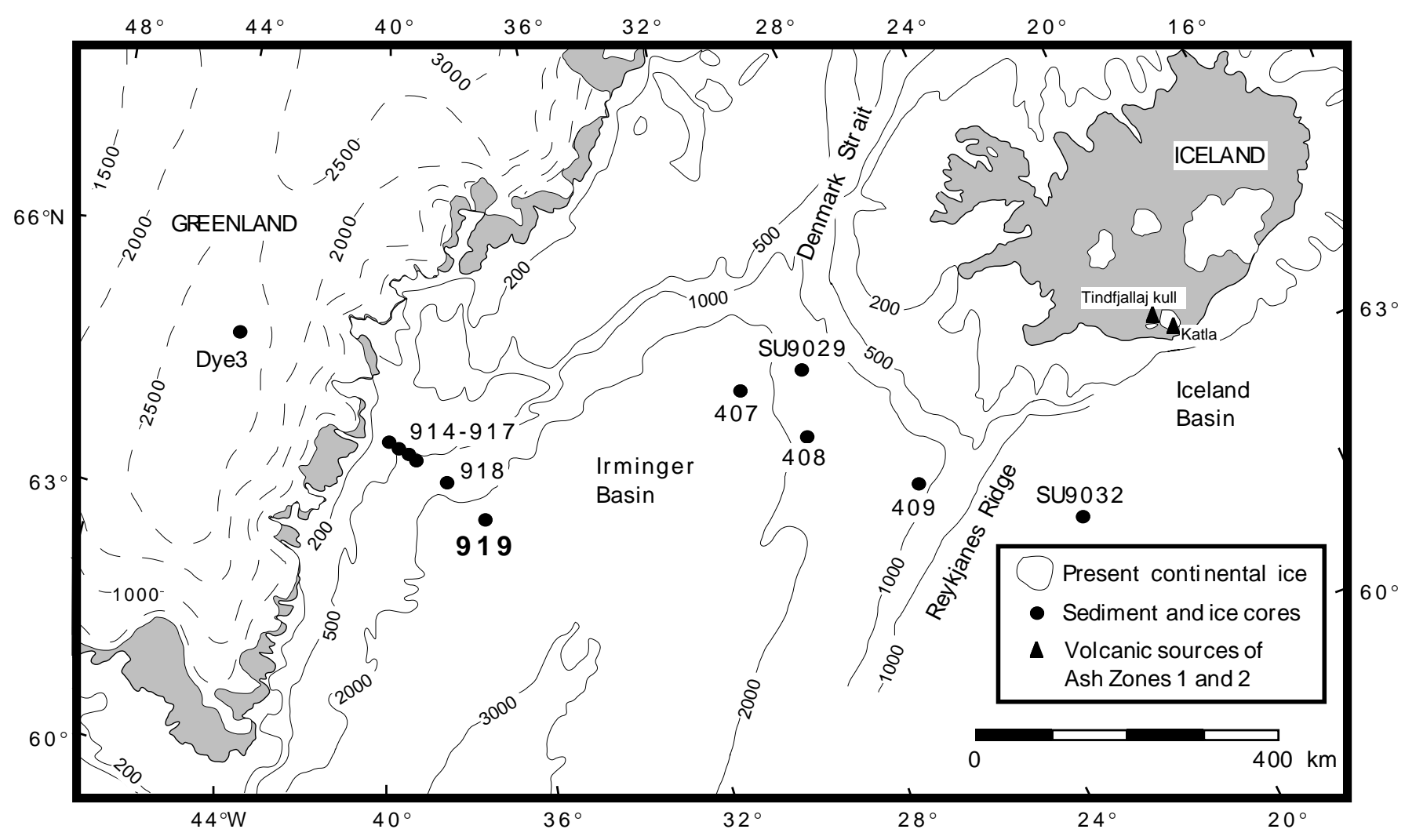

Figure 1. Map showing location of piston and DSDP-ODP cores in the Irminger Basin and ice cores in southern Greenland.

Site 919 is only approximately $200 \mathrm{~km}$ from the present shoreline of East Greenland and was therefore probably subject to repeated episodes of large fluxes of terrigenous material transported by turbidity currents and slumping from the prograding Greenland shelf. Drilling at Sites 914-917 on the continental shelf (Fig. 1), only 40-75 km from the Greenland coast, shows evidence of the extension of the Greenland Ice Sheet (GIS) at least $75 \mathrm{~km}$ onto the continental shelf (Larsen et al., 1994). While full-scale glaciations occurred in Greenland during the late Pleistocene glacial maxima, rapid accumulation of glacio-marine sediments probably diluted any other type of sediment in the Site 919 region.

Glauconitized hardgrounds, showing erosional features and poorly sorted sand at their tops, were found in lithologic Unit II of Site 918 (Shipboard Scientific Party, 1994b) (Fig. 1). These sedimentological features suggest that sand was transported and deposited by a highly concentrated flow from the north (i.e., the North Atlantic Bottom Water [NABW] overflow into the Irminger Basin). Seismic transects off southeast Greenland indicate deposition of contourites or sediment drifts in addition to massive turbidites. The first are interpreted to be related to the NABW overflow from the NorwegianGreenland Sea across the Denmark Strait (L. Clausen, pers. comm., 1995).

This sedimentological environment indicates that the tephra preserved in Site 919 sediments were deposited during a period of high accumulation rates. Such a high-resolution marine record is comparable with the time frame of the atmospheric record in Greenland ice cores.

\section{TEPHRA IN THE IRMINGER BASIN AND GREENLAND}

\section{Deep-Sea Tephra Record in the Irminger Basin}

Prior to Leg 152, only two sites, Sites 407 and 408 (DSDP Leg 49), had been drilled in the Irminger Basin (Luyendyk, Cann, et al.,
1979; Fig. 1). Several layers of volcanic ash were recovered from these two holes, southwest of Iceland (Varet and Metrich, 1979). At least five tephra layers were found in the Pleistocene calcareous sandy mud, and thick ash layers occur also in Pliocene and middle Miocene sediments. Clastic fragments of volcanic origin and ash layers are nearly as abundant at Site 407 as at Site 408. Two types of glasses occur in an ash-rich zone, located in the uppermost $10 \mathrm{~m}$, with $10 \%$ to $25 \%$ volcanogenic fragments: a brown basaltic glass and a colorless rhyolitic glass. A few crystals of alkali feldspar, plagioclase, and quartz are associated with the colorless glass. A similar association of two glasses was found at deeper levels, at 36.5 and 147 mbsf. Thin discrete layers of essentially fresh and/or altered basaltic glass occur at 39, 115, 212.5, and 218.5 mbsf in Hole 408, in addition to a mixed tephra layer ( $80 \%$ basaltic and $20 \%$ rhyolitic glass) found at 115 mbsf. Numerous dark ash pods were found in the 200-209 mbsf interval, and they probably result from reworking of former ash fall layers. Two samples of rhyolitic glass fragments were selected for microprobe analysis, one from a mid-Pliocene layer in Hole 407 and one from a middle Miocene layer in Hole 408. Both analyses show an alkali rhyolite composition (Varet and Metrich, 1979). Their normative compositions plot along the quartz-feldspar cotectic for a water pressure of $1 \mathrm{~kb}$ in the granite system quartz-albite-orthoclase. An unpublished analysis of brown glass recovered from Miocene sediment in Hole 408 indicates a tholeiitic basalt composition low in potassium. Based on this limited study of tephra and the poor recovery (40\% and $61 \%$, respectively) in Holes 407 and 408, no reconstruction of the volcanic activity in the region has been proposed.

Sedimentological and chemical analyses were recently carried out on marine tephra recovered in a piston core raised from the central part of the Irminger Basin (Lacasse et al., 1996). Core SU9029 is 11.2 $\mathrm{m}$ long and was recovered from $1600 \mathrm{~m}$ water depth at $63^{\circ} 52^{\prime} \mathrm{N}$, $28^{\circ} 56^{\prime} \mathrm{W}$, approximately $450 \mathrm{~km}$ northeast of ODP Site 919 (Fig. 1). With a mean sedimentation rate of about $2.1 \mathrm{~cm} / \mathrm{k} . y$., core SU9029 spans the last 500 k.y. down to isotopic Stage 13. Only two depth intervals, at 91-103 and 556-568 mbsf, were found to have high con- 
centrations of dispersed colorless glass shards. Their compositional and granulometric characteristics suggest a complex depositional process, with initial fallout of tephra on pack-ice north of Iceland followed by ice-rafting deposition from the Denmark Strait prior to bioturbation. From their stratigraphic position and glass chemistry, they have been correlated with the ice-rafted ash Zone $2(\sim 55-57.5 \mathrm{ka})$ and ash Zone $3(\sim 305 \mathrm{ka})$ in the North Atlantic. The $\delta^{18} \mathrm{O}$ record indicates that they were deposited during a cold spell when pack-ice covered the seas north of Iceland. The transitional composition of ash Zone 2 and the tholeiitic composition of ash Zone 3 indicate that they originated from the Southeastern Volcanic Zone and the central rift system in Iceland, respectively. Due to coring disturbance at the top of the sequence, ash Zone 1 ( 11-11.1 ka; Bard et al., 1994) was not found.

\section{Tephra in Greenland Ice Cores}

Volcanic activity has been recorded in Greenland ice cores through the occurrence of acidity peaks as a result of sulfate aerosol deposition (Hammer, 1977, 1984; Zielinski et al., 1994, 1996) and fine tephra horizons (Fiacco, 1991; Palais et al., 1991, 1992; Ram and Gayley, 1991; Fiacco et al., 1993; Grönvold et al., 1995). Study of volcanic ash particles in ice cores has provided valuable information for ice core dating and atmospheric transport patterns, and it can be used with the marine record as indicators of paleovolcanic activity. Glaciochemical seasonal indicators along ice cores have provided a precise dating of the related volcanic events.

The occurrence of volcanic aerosols in the Greenland ice sheet was first reported by Hammer (1977) from the Dye 3 core, about 400 $\mathrm{km}$ northwest of ODP Site 919 (Fig. 1). Only one volcanic dust layer was observed in the uppermost section of the Dye 3 core. Some 10$100 \mathrm{mg}$ of ash per kilogram of ice is generally needed to give a visible coloring of the ice (Hammer, 1984). The presence of volcanic impurity was therefore assessed using the measurement of electrical conductivity $\left(\mathrm{S} \mathrm{m}^{-1}\right)$ along ice cores and by measuring the concentration $\left(\mu \mathrm{g} \mathrm{kg}^{-1}\right)$ of microparticles (i.e., diameter less than $\left.2-5 \mu \mathrm{m}\right)$ from melted ice samples. It was found that periods of high northern hemispheric volcanic activity have not been associated with elevated microparticle concentrations in ice cores, whereas they are indicated by specific high conductivity, for example the Laki 1783 eruption in Iceland (Hammer, 1977). High conductivity values have resulted from the fallout of acids following large eruptions and are correlated with acidity spikes ( $\mu$ equiv $\mathrm{H}^{+} \mathrm{kg}^{-1}$ ) along ice cores (Hammer, 1984). Surprisingly, most of the historical and postglacial Icelandic eruptions, with the exception of the A.D. 1362 Oræfajökull eruption (Palais et al., 1991), are not recorded as volcanic ash horizons in Greenland ice cores, but only as acidity and sulfate $\left(\mathrm{SO}_{4}{ }^{2-}, \mathrm{ppb}\right)$ concentration peaks (Hammer, 1984; Zielinski et al., 1994). The stratigraphic position of the strongest postglacial acid signals was shown to correlate well between different Greenland coring sites: Crête: $71^{\circ} 07^{\prime} \mathrm{N}, 37^{\circ} 19^{\prime} \mathrm{W}$; Dye 3: $65^{\circ} \mathrm{N}, 44^{\circ} \mathrm{W}$; and Camp Century: $77^{\circ} 11^{\prime} \mathrm{N}, 61^{\circ} 09^{\prime} \mathrm{W}$ (Hammer, 1984).

The rare postglacial microparticle concentration peaks observed in Greenland ice cores have been correlated to distal volcanic events, such as the A.D. 130 Taupo eruption in a Dye 3 ice core (Hammer, 1984), the A.D. 1479-1480 Mt. St. Helens, Washington, and the A.D. 1259 El Chichon eruptions in GISP2 (Summit) ice cores (Palais et al., 1992; Fiacco et al., 1993). For the possible El Chichon event, volcanic glass shards were also reported, in addition to acidity spikes in an ice core from the Antarctic Ice Sheet, demonstrating the possible interhemisphere transport of volcanic ash (Palais et al., 1990, 1992).

With the deepening of the Dye 3 Site in southern Greenland, additional ash bands have been reported (Ram and Gayley, 1991). Platy glass shards up to several hundred micrometers in diameter were found in two particle aggregates in a 78-cm section, between 1949.27 and $1950 \mathrm{~m}$ below the snow surface. Using the chronology of Dansgaard et al. (1985), Ram and Gayley estimate that this depth interval spans approximately $400 \mathrm{yr}$. Glass particles from the lowermost aggregate were analyzed by energy-dispersive X-ray, and they indicate rhyolitic, basaltic, and dacitic compositions. This horizon was correlated to the marine ash Zone 2 in the North Atlantic, based on the major element concentration of the rhyolitic glass particles and an age estimate of the ice interval studied of $\sim 70 \mathrm{ka}$. This age estimate must be viewed with caution, however, because it has been difficult to date the Wisconsinian ice from Dye 3 (Dansgaard et al., 1985). It is also possible that the apparent double appearance of ash aggregates may be an artifact resulting from uneven subsurface topography (K. Grönvold, pers. comm., 1995).

Several ash horizons in the Greenland Summit GRIP ice core have recently been identified and correlated based on their chemical composition to corresponding land-based and marine tephra layers (Grönvold et al., 1995). Absolute dating of the tephra was inferred by counting annual layers, providing an accurate age for the Icelandic eruptions: Settlement Layer, A.D. $871 \pm 2$ yr; Saksunarvatn, 10,180 $\pm 60 \mathrm{yr}$; ash Zone 1, Skógar Tephra (Vedde Ash), 11,980 $\pm 80 \mathrm{yr}$ BP. An age of $52 \mathrm{ka}$ for ash Zone 2 was derived from the extrapolated ice flow model. Interpretation of volcanically produced sulfate peaks remains, however, the best method to study time series of explosive volcanism in ice cores. Such a record has been extended over the last $110 \mathrm{ka}$ from the GISP2 ice core (Zielinski et al., in press). A minimum of 850 events ( 700 of these from 9 to $110 \mathrm{ka}$ ) have been recorded with the highest $\mathrm{SO}_{4}{ }^{2-}$ concentrations exceeding $500 \mathrm{ppb}$.

\section{METHODS}

\section{Sampling Resolution and Sample Preparation}

All of the discrete ash layers that were identified in Holes 919A and 919B by the Shipboard Scientific Party were studied (Shipboard Scientific Party, 1994a). Ash layers or ash zones thicker than $10 \mathrm{~cm}$ were sampled at two different depth intervals, whereas only a single sample was taken from thinner horizons (Table 1). Each sample of bulk sediment was dried and weighed. The carbonate fraction was removed using hydrochloric acid. The carbonate-free residue was rinsed and wet-sieved through a set of screens ( $1 \phi$ interval) down to $5.5 \phi(22 \mu \mathrm{m})$.

\section{Grain-Size and Modal Analyses}

Each sieved fraction $(>5.5 \phi)$ was dry-weighed. The remaining fine fraction was analyzed using an automated Elzone 150+ particle analyzer with a $48-\mu \mathrm{m}$ orifice and a conducting solution of sodium pyrophosphate $(4 \%)$. This instrument uses the electrosensing technique to determine particle size and can detect particles down to $1 \mu \mathrm{m}$ in size. The combined method of wet sieving and Elzone thus allows analysis of sediment with a large grain size range. Grain-size characteristics (median and mean sizes, sorting and skewness) were derived from the cumulative granulometric curve (Folk, 1974; Table 1).

Abundances of the different components was estimated by counting approximately 300-500 grains under a microscope (Table 1). This analysis was carried out on the $62.5-125 \mu \mathrm{m}$ or $125-250 \mu \mathrm{m}$ fractions that contain both the most representative and reliable material for mineral determination. Pyroclastic components were divided into several groups: colorless shards, brownish glass or sideromelane, opaque: tachylite or oxides. Minerals such as quartz (essentially detrital), plagioclase, clinopyroxene, olivine, and amphibole were counted as well as lithics and siliceous biogenic material (radiolarian and diatom).

\section{Electron Microprobe Analysis of Major Elements}

All microprobe analyses were performed on the coarse fraction $>62.5-125 \mu \mathrm{m}$ or $>125-250 \mu \mathrm{m}$. The major element composition of volcanic glass particles was determined at a specific depth interval in each ash layer and ash zone (up to 15 and 30 individual analyses of 
Table 1. Depth, $\delta^{18} \mathrm{O}$ dating, thickness, grain-size characteristics and composition of ash layers, pods, and ash zones of Site 919.

\begin{tabular}{|c|c|c|c|c|c|c|c|c|c|c|c|c|c|c|c|c|}
\hline \multirow[b]{2}{*}{ Layer } & \multirow[b]{2}{*}{$\begin{array}{l}\text { Core, section, } \\
\text { interval }(\mathrm{cm})\end{array}$} & \multirow[b]{2}{*}{$\begin{array}{l}\text { Depth } \\
\text { (mbsf) }\end{array}$} & \multirow{2}{*}{$\begin{array}{c}\delta^{18} \mathrm{O} \\
\text { age } \\
\text { (ka) }\end{array}$} & \multirow[b]{2}{*}{ Type } & \multirow[b]{2}{*}{ Color } & \multirow[b]{2}{*}{$\begin{array}{c}\text { Thickness } \\
(\mathrm{cm})\end{array}$} & \multirow[b]{2}{*}{$\begin{array}{c}\text { Top-bottom } \\
\text { (mbsf) }\end{array}$} & \multicolumn{4}{|c|}{ Grain-size characteristics } & \multicolumn{2}{|c|}{ Glass } & \multirow{2}{*}{$\begin{array}{c}\text { Tach./ } \\
\text { Opaq. } \\
(\%)\end{array}$} & \multirow{2}{*}{$\begin{array}{c}\text { Plagio./ } \\
\text { K.Feld. } \\
(\%)\end{array}$} & \multirow[b]{2}{*}{$\underset{(\%)}{\mathrm{Cpx} .}$} \\
\hline & & & & & & & & $\varnothing 50$ & $\mathrm{Mz}$ & Sg & Sk & $\begin{array}{l}\text { Col. } \\
(\%)\end{array}$ & $\begin{array}{l}\text { Sid. } \\
(\%)\end{array}$ & & & \\
\hline \multicolumn{17}{|l|}{$152-919 \mathrm{~A}-$} \\
\hline $\begin{array}{l}\mathrm{A}(*) \\
\mathrm{A}(*)\end{array}$ & $1 \mathrm{H}-1,11-12$ & $\begin{array}{l}0.11 \\
0.29\end{array}$ & $11-11.1$ & DA & & & & & & & & 27 & $\begin{array}{r}8 \\
28\end{array}$ & 10 & 5 & 1 \\
\hline $\begin{array}{l}\mathrm{A}(*) \\
\mathrm{B}\end{array}$ & $\begin{array}{l}\mathrm{H}-\mathrm{H}-1,29-30 \\
2 \mathrm{H}-2,140-141\end{array}$ & $\begin{array}{r}0.29 \\
10.90\end{array}$ & $\begin{array}{l}11-11.1 \\
55-57\end{array}$ & AL & Dark gravish & 3.0 & $1090-10.93$ & 4.68 & 489 & 100 & 032 & 1 & 81 & $\begin{array}{l}11 \\
8\end{array}$ & 11 & \\
\hline $\mathrm{C}$ & $2 \mathrm{H}-3,18-19$ & 11.18 & $55-57$ & $\mathrm{AL}$ & Grayish brown & 5.0 & $11.15-11.20$ & 4.36 & $\begin{array}{l}4.09 \\
4.30\end{array}$ & 1.46 & -0.06 & 93 & $\begin{array}{r}01 \\
3\end{array}$ & $\begin{array}{l}8 \\
1\end{array}$ & $\begin{array}{l}4 \\
1\end{array}$ & \\
\hline $\mathrm{D}$ & $7 \mathrm{H}-4,135-138$ & 61.35 & $488-489$ & $\mathrm{AL}$ & Black & 1.0 & $61.36-61.37$ & 6.09 & 5.82 & 2.32 & -0.18 & 1 & 31 & 23 & 4 & 10 \\
\hline E & $8 \mathrm{H}-1,94-95$ & 65.94 & $539-540$ & $\mathrm{AP}$ & Black & & & 6.68 & 6.41 & 1.73 & -0.23 & & 15 & 11 & 2 & 1 \\
\hline $\mathrm{F}$ & $10 \mathrm{H}-2,112-113$ & 86.62 & $664-665$ & $\mathrm{AP}$ & Grayish brown & & & 6.45 & 6.10 & 1.93 & -0.27 & & 37 & 30 & 2 & 1 \\
\hline \multicolumn{17}{|l|}{ 152-919B- } \\
\hline $\mathrm{G}(*)$ & $1 \mathrm{H}-1,24-25$ & 0.24 & $11-11.1$ & DA & & & & & & & & 10 & 25 & 8 & 4 & 1 \\
\hline $\mathrm{G}(*)$ & $1 \mathrm{H}-1,38-39$ & 0.38 & $11-11.1$ & $\mathrm{DA}$ & & & & & & & & 27 & 13 & 6 & 3 & 2 \\
\hline $\mathrm{H}$ & $2 \mathrm{H}-1,106-109$ & 10.26 & $55-57$ & $\mathrm{AL}$ & Black & 4.0 & $10.26-10.30$ & 4.77 & 5.12 & 1.35 & 0.39 & 42 & 54 & 1 & 2 & \\
\hline I & $2 \mathrm{H}-2,24-27$ & 10.94 & $55-57$ & $\mathrm{AL}$ & Light brown & 3.0 & $10.91-10.94$ & 4.36 & 4.48 & 1.64 & 0.11 & 98 & 1 & 1 & & \\
\hline \multicolumn{17}{|c|}{ Not cored from 18.7 to $90.0 \mathrm{mbsf}$} \\
\hline $\mathrm{J}$ & $5 \mathrm{H}-5,87-88$ & 115.87 & $765-766$ & AP & Black & & & 5.00 & 4.93 & 1.25 & -0.09 & & 51 & 43 & 4 & 1 \\
\hline $\mathrm{K}$ & $6 \mathrm{H}-6,22-25$ & 126.22 & $?$ & DA & & & & & & & & 82 & 2 & 1 & 6 & \\
\hline $\mathrm{L}$ & $6 \mathrm{H}-6,87-91$ & 126.87 & ? & $\mathrm{AL}$ & Black & 4.0 & $126.87-126.91$ & 5.36 & 5.33 & 2.32 & -0.02 & & 40 & 32 & 5 & \\
\hline $\mathrm{M}$ & $8 \mathrm{H}-3,94-95$ & 141.44 & ? & $\mathrm{AP}$ & & & & 4.59 & 4.45 & 1.62 & -0.13 & & 38 & 12 & 13 & \\
\hline
\end{tabular}

Notes: $\varnothing 50=$ median size, $\mathrm{Mz}=$ graphic mean, $\mathrm{Sg}=$ sorting coefficient, and $\mathrm{Sk}=$ graphic skewness, after Folk $(1974)$. Col. $=$ colorless glass shards (platy and vesicular) and micropumice. Sid. $=$ sideromelane $($ brownish glass), Tach. $=$ tachylite, Opaq. $=$ opaque, Plagio. $=$ plagioclase, $\mathrm{K}$. Feld. $=\mathrm{K}$ feldspar, and Cpx. $=$ clinopyroxene. $*=$ ash layer sampled at two depth intervals. $\mathrm{DA}=$ dispersed ash, $\mathrm{AL}=$ ash layer, and $\mathrm{AP}=$ ash pod. 
glass shards for homogeneous and heterogeneous glass composition, respectively) using a Cameca electron microprobe. Our analytical technique follows the recommendations adopted for the standardization of the chemical analysis of tephra (INQUA Inter-Congress Committee on Tephrochronology, 1990). A beam current of $10 \mathrm{nA}$ with an accelerating voltage of $15 \mathrm{kV}$ was used. Na loss was minimized for silicic glass analysis by using a beam defocused to $10 \mu \mathrm{m}$ and by collecting counts at regular time intervals $(2 \mathrm{~s})$ and extrapolating the decay curve back to count initiation (Nielsen and Sigurdsson, 1981). Calibrations of silicic and basaltic glass compositions were made by running the natural glass standards $\mathrm{KN}-18$ (comendite obsidian from Kenya; Nielsen and Sigurdsson, 1981) and VG-2 (basaltic glass from the Juan de Fuca Ridge), respectively.

\section{Neutron Activation Analysis of Trace Elements}

Neutron activation was performed on bulk ashes for all the discrete ash layers with less than 5\%-10\% crystals. Each tephra sample (31-62 $\mu \mathrm{m}$ or $62-125 \mu \mathrm{m}$ fraction) was irradiated with a flux of $10^{14}$ $\mathrm{n} / \mathrm{cm}^{2} / \mathrm{s}$ for $1-3 \mathrm{hr}$ in aluminum sleeves at Centre d'Etudes Nucléaires of Saclay, France. Measurements of trace element concentrations were made using an intrinsic Ge detector of $100 \mathrm{~cm}^{3}$, using granite and basalt standards (GSN and BEN) from the Centre de Recherches Pétrographiques et Géochimiques (CRPG) of Nancy, France. Quantification was done following automatic peak search, nuclear identification, and calculation for element concentration. Analytical precision is $10 \%$ for $\mathrm{Sc}, \mathrm{Co}, \mathrm{Zr}, \mathrm{Cs}, \mathrm{La}, \mathrm{Ce}, \mathrm{Sm}, \mathrm{Eu}, \mathrm{Tb}, \mathrm{Yb}, \mathrm{Hf}, \mathrm{Ta}$, and $\mathrm{Th} ; 15 \%$ for $\mathrm{Cr}, \mathrm{Sb}, \mathrm{Ba}, \mathrm{Nd}$, and $\mathrm{Lu}$; and $20 \%$ for $\mathrm{U}$.

\section{LITHOLOGY AND STRATIGRAPHY}

Tephra were sampled in lithologic Unit I, from Cores 152-919A$1 \mathrm{H}$ through $10 \mathrm{H}$ and Cores $152-919 \mathrm{~B}-1 \mathrm{H}$ through $8 \mathrm{H}$, which is composed of silty clay, clayey silt, and clay with silt (Shipboard Scientific Party, 1994a). Bedding and poor sorting in the sediment were observed. These sedimentological features are interpreted to be indicative of deposition from the melting of sediment-rich pack ice and icebergs, combined with subsequent turbidite flow along the seafloor. Biogenic components occur as diatoms, sponge spicules, foraminifers, and calcareous nannofossils. Variation in calcareous microfossil abundance observed especially in the lower half of the sequence, between 65 and 147 mbsf, may reflect change in carbonate production and influx of terrigenous material as a result of glacial-interglacial oscillations. Among the terrigenous material, quartz is the most abundant and is commonly associated with amphibole, clinopyroxene, and opaque minerals. Garnet, epidote, and sphene were found occasionally. This terrigenous material is likely derived from a continental source in East Greenland. Dropstones $(0.2-5 \mathrm{~cm}$ in diameter) of basalt, gneiss, dolerite, and gabbro, among others, are scattered throughout the lithology. The dominant basaltic lithology $(50 \%$ of the total) indicates an origin from the Tertiary basaltic formation of the Scoresby Sund region in East Greenland (Shipboard Scientific Party, 1994a). Dropstones were found, however, to be less abundant than in the other holes drilled during Leg 152, due to the greater distance from East Greenland.

\section{DATING OF THE TEPHRA LAYERS}

Major discrepancies remain between the interpretation of the isotope stratigraphy (strontium and oxygen) and the biomagnetostratigraphy for the lowermost $50 \mathrm{~m}$ of Hole 919B (Shipboard Scientific Party, 1994a; Israelson and Spezzaferri, this volume; Flower, this volume). The first method indicates a late Quaternary age for this section, whereas a higher age is suggested from the study of nannofossil and foraminifer assemblages, placing the Pliocene/Pleistocene boundary at about 128 mbsf (Shipboard Scientific Party, 1994a).
Only the Brunhes/Matuyama boundary (780 ka) has been unambiguously identified at about 120.5 mbsf (Cande and Kent, 1992; Shipboard Scientific Party, 1994a; Fig. 2). No precise age can therefore be suggested for the oldest tephra below this depth.

Oxygen $\left(\delta^{18} \mathrm{O}\right)$ and carbon $\left(\delta^{13} \mathrm{C}\right)$ isotope contents of foraminifers were measured along Hole 919A (Flower, this volume). An age model for this section has been suggested, based on the isotope stage boundaries of Imbrie et al. (1984). The 93.59-m sequence of Hole 919A spans approximately the last $690 \mathrm{ka}$ down to oxygen isotope Stage 17 (Fig. 2). Mean $\delta^{18} \mathrm{O}$ ages of the tephra were determined by linearly interpolating between isotopic stage boundaries. However, due to the limited resolution of the record (one sample per core section) refined isotopic ages were suggested for the ash layers and ash zones in Site 919 sediments that have been correlated to other known stratigraphic makers in North Atlantic sediments (e.g., ash Zone 1 and ash Zone 2) (Smythe et al., 1985; Bard et al., 1994; Lacasse et al., 1995, 1996).

\section{DESCRIPTION AND GRAIN-SIZE CHARACTERISTICS OF TEPHRA LAYERS}

Three major types of tephra occurrence within the sediment were defined, based on their visual characteristics and modal composition. These include ash layers (type AL), dispersed ash (type DA), and ash pods (type AP). Each type was assigned a letter, A through M (Table 1). Six discrete ash layers (type AL) were studied within the depth interval 0-142 mbsf, corresponding to the Pliocene-Pleistocene period (Shipboard Scientific Party, 1994a). They show a more or less sharp contact with the underlying and overlying sediment, indicative of limited mixing by bioturbation, in a high sedimentation rate environment. Thickness varies between 1 (Layer D) and $5 \mathrm{~cm}$ (Layer C). Ash color varies, including light brown, grayish brown, dark gray, and black. Crystals make up to $15 \%$ of the total components in the $3 \phi$ fraction (e.g., Layer D; $4 \%$ feldspar, $10 \%$ clinopyroxene). Abundances of the different components were found to depend strongly on the size fraction studied. For example the correlative Layers B (4 $\phi$ fraction) and $\mathrm{H}$ (3 $\phi$ fraction) in Holes 919A and 919B exhibit a difference in colorless shards and brownish glass that appears to be mainly the result of grain size (Table 1). Sideromelane, tachylite, crystal and lithic grains are less abundant in the coarse fractions $(\phi \leq 3)$ because of their relatively high density and rounded shape in comparison with the less dense and platy colorless shards (i.e., essentially bubble walls). Following distal airborne transport, the former tend to settle through the air and water column more rapidly and closer to source than the latter. Layers C and I in Holes 919A and 919B comprise essentially colorless shards ( $>90 \%$ in the $3 \phi$ size fraction) and can be considered as homogeneous in composition. Although its fine sand fraction shows a high concentration of colorless shards (around $80 \%$ ), Layer $\mathrm{K}$ at 126 mbsf in Hole 919B was identified as an ash zone because of its high clay content and its dispersed nature in the sediment.

Grain-size characteristics of the discrete ash layers (type AL) and ash pods (AP) were determined, including median diameter ( $\phi 50)$, graphic mean $(\mathrm{Mz})$, graphic standard deviation (Sg, sorting coefficient), and graphic skewness (Sk) (Folk, 1974; Table 1). All of the tephra fall into the fine to coarse silt size classes, between 4 and $7 \phi$ (Folk, 1974). By comparison, the ash layers of Site 907, located 350 $\mathrm{km}$ north of Iceland, are generally coarser, between 3 and $5 \phi$ (Lacasse et al., in press). The finer grain size of tephra layers found at Site 919 can be explained by their greater distance from the same potential volcanic sources in Iceland, around $750 \mathrm{~km}$ to the northeast. Their relatively good sorting $(1 \leq \mathrm{Sg} \leq 2.3)$ indicates, however, that they have a primary fallout origin. Both grain size and sorting of tephra from Site 919 in the Irminger Basin are compatible with longrange airborne transport of these ashes toward south Greenland from volcanic sources located on Iceland. 


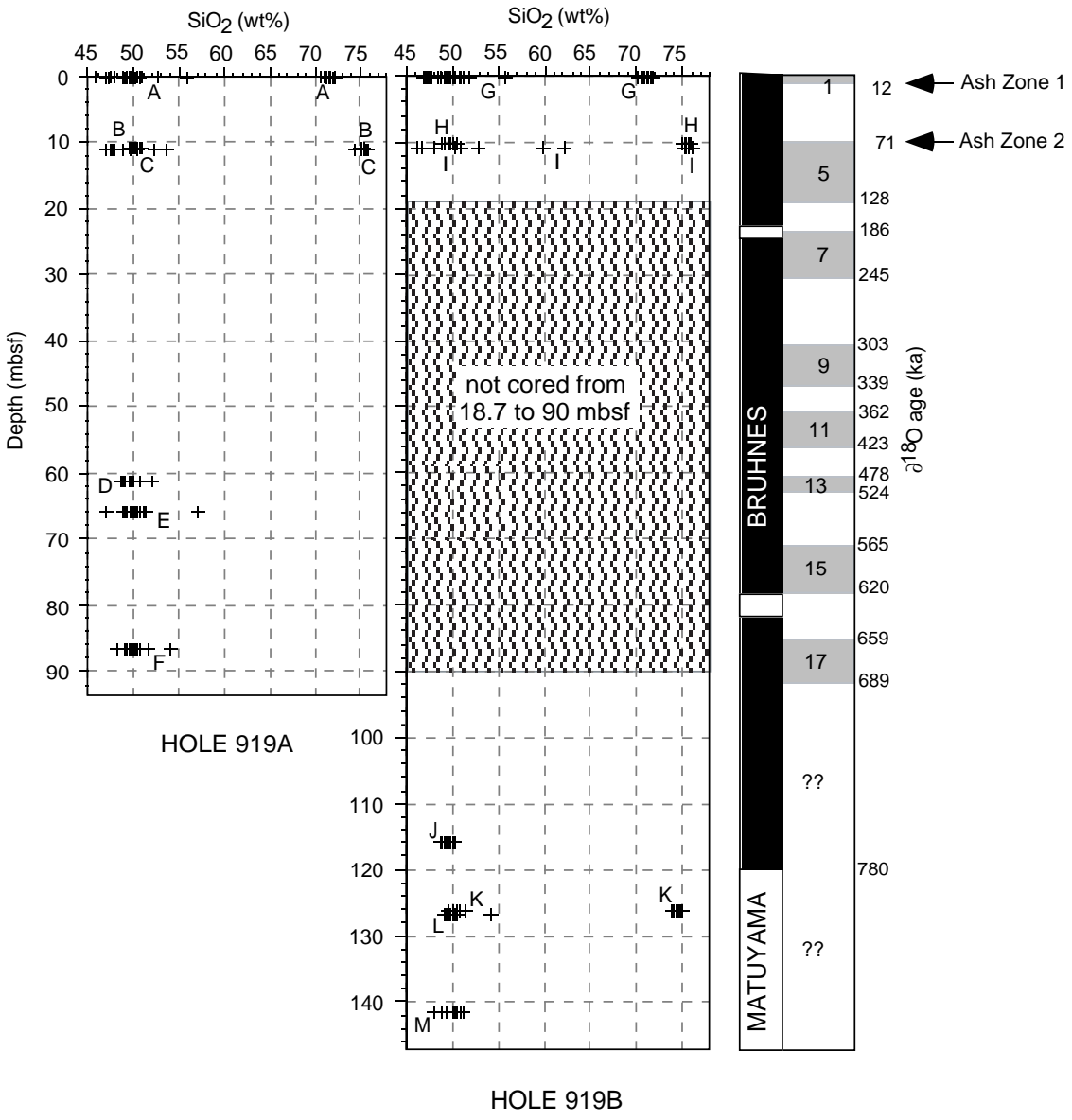

Figure 2. Stratigraphic position and silica content of Pliocene-Pleistocene ash layers in Holes 919A and 919B. Paleomagnetic and $\delta^{18} \mathrm{O}$ ages are from Shipboard Scientific Party (1994a) and Flower (this volume), respectively. Also shown are ash Zone 1 (1111.1 ka after Bard et al., 1994) and ash Zone 2 (55$57.5 \mathrm{ka}$ after Smythe et al., 1985; Lacasse et al., 1996). an Icelandic affinity (Fig. 3). None of the tephra can be considered to have an affinity with the trachy basaltic rock series of Jan Mayen (Imsland, 1984). Furthermore, as it was pointed out for the Pliocene and Pleistocene tephra of Site 907, microprobe analyses of all the basaltic glass shards from Holes 919A and 919B indicate a potassium content higher than $0.2 \mathrm{wt} \%$, which represents the upper limit for basaltic glass originated from the Mid-Atlantic Ridge (Sigurdsson, 1981; Lackschewitz and Wallrabe-Adams, 1991; Lackschewitz et al., 1994). The Reykjanes Ridge, approximately $500 \mathrm{~km}$ east of Site 919 , is not considered a likely source of volcaniclastic sedimentation in this region during the Quaternary. The different volcanic systems in Iceland should therefore be considered as the exclusive sources of the Pliocene-Pleistocene tephra found at Site 919.

\section{Basic and Intermediate Glass}

Microprobe analytical totals of silicic glasses range between about 95.5 and $99.5 \%$ (Table 2). Difference from $100 \%$ is largely attributed to the water content of the glass. Totals for individual analyses of mafic glass shards range between $98 \%$ and $101.5 \%$ (Table 3 ). All of the layers can be classified into two compositional groups: heterogeneous layers with mafic and silicic glass composition (Layers A, B, and C in Hole 919A and Layers G, H, I, and K in Hole 919B, with $\mathrm{SiO}_{2}$ ranging between 45 and $76 \mathrm{wt} \%$ ) and homogeneous layers with basaltic glass composition (Layers D, E, and F in Hole 919A and Layers J, L, and $\mathrm{M}$ in Hole 919B, with $\mathrm{SiO}_{2}$ ranging between 46 and $52 \mathrm{wt} \%$ ). Very few glass shards were found with a basaltic andesite composition, with $\mathrm{SiO}_{2}$ ranging between 52 and $57 \mathrm{wt} \%$.

A total alkali-silica (TAS) diagram was used to classify glass shards compositions and to discriminate between the only two potential Pliocene-Pleistocene volcanic sources in the North Atlantic region (i.e., Iceland and Jan Mayen). All of the tephra plot within two major TAS fields defining basalt and rhyolite compositions, showing
Individual glass analyses of the basic and intermediate glass shards are plotted as a function of $\mathrm{SiO}_{2}, \mathrm{Al}_{2} \mathrm{O}_{3}, \mathrm{FeO} *$, and $\mathrm{CaO}$ vs. $\mathrm{MgO}$ in Figure 4. $\mathrm{MgO}$ concentrations vary between 8 and $3.5 \mathrm{wt} \%$, showing a negative correlation with increasing $\mathrm{CaO}$ content (Fig. 4D). Trends for silica, alumina and iron contents show a kink between 5 and $5.5 \mathrm{wt} \% \mathrm{MgO}$, corresponding to the compositional boundary between basaltic and intermediate glass. These breaks in trends can be related to changes in associated phase assemblages, with fractionation or accumulation of olivine and/or spinel, and crystallization of plagioclase and clinopyroxene. Similar variation trends were found for different tholeiitic volcanic systems in Iceland, showing a break at a $\mathrm{Mg}$ value (i.e., atomic ratio $100 \mathrm{Mg} / \mathrm{Mg}+\mathrm{Fe}^{2+}$ ) of about 70 (Meyer et al., 1985).

Among the major elements, $\mathrm{TiO}_{2}$ and $\mathrm{K}_{2} \mathrm{O}$ show the largest compositional variation in Iceland basalts (Jakobsson, 1979b; Larsen, 
Table 2. Electron microprobe analyses and normative composition of silicic glassy tephra from Site 919.

\begin{tabular}{|c|c|c|c|c|c|c|c|c|c|}
\hline Hole: & 919A & 919A & 919A & 919A & 919B & 919B & 919B & 919B & 919B \\
\hline Core, section: & $1 \mathrm{H}-1$ & $1 \mathrm{H}-1$ & $2 \mathrm{H}-2$ & $2 \mathrm{H}-3$ & $1 \mathrm{H}-1$ & $1 \mathrm{H}-1$ & 2H-1 & $2 \mathrm{H}-2$ & $6 \mathrm{H}-6$ \\
\hline Interval $(\mathrm{cm})$ : & $11-12$ & $29-30$ & $140-141$ & $18-19$ & $24-25$ & $38-39$ & $106-109$ & $24-27$ & $22-25$ \\
\hline Layer: & $\mathrm{A}\left({ }^{*}\right)$ & $\mathrm{A}(*)$ & B & C & $\mathrm{G}(*)$ & $\mathrm{G}\left({ }^{*}\right)$ & $\mathrm{H}$ & I & K \\
\hline Type: & DA & DA & $\mathrm{AL}$ & $\mathrm{AL}$ & DA & DA & $\mathrm{AL}$ & $\mathrm{AL}$ & DA \\
\hline$N:$ & 9 & 10 & 15 & 15 & 11 & 15 & 15 & 14 & 20 \\
\hline $\mathrm{SiO}_{2}$ & $71.00(0.49) \dagger$ & $70.88(0.66)$ & $72.29(0.55)$ & $73.05(0.60)$ & $70.70(0.47)$ & $70.25(0.50)$ & $72.16(0.53)$ & $72.36(0.44)$ & $71.03(0.52)$ \\
\hline $\mathrm{TiO}_{2}$ & $0.29(0.04)$ & $0.28(0.05)$ & $0.17(0.05)$ & $0.18(0.05)$ & $0.28(0.04)$ & $0.31(0.05)$ & $0.15(0.03)$ & $0.15(0.04)$ & $0.25(0.05)$ \\
\hline $\mathrm{Al}_{2} \mathrm{O}_{3}$ & $13.63(0.22)$ & $13.49(0.13)$ & $11.46(0.14)$ & $11.74(0.25)$ & $13.49(0.12)$ & $13.48(0.22)$ & $11.53(0.13)$ & $11.49(0.18)$ & $9.04(0.17)$ \\
\hline $\mathrm{FeO}^{*}$ & $3.82(0.12)$ & $3.67(0.19)$ & $2.46(0.12)$ & $2.47(0.15)$ & $3.80(0.19)$ & $3.78(0.14)$ & $2.48(0.10)$ & $2.47(0.13)$ & $4.73(0.17)$ \\
\hline $\mathrm{MnO}$ & $0.12(0.04)$ & $0.12(0.04)$ & $0.06(0.05)$ & $0.07(0.05)$ & $0.16(0.06)$ & $0.13(0.07)$ & $0.07(0.04)$ & $0.07(0.05)$ & $0.23(0.05)$ \\
\hline $\mathrm{MgO}$ & $0.23(0.01)$ & $0.22(0.02)$ & $0.00(0.01)$ & $0.00(0.01)$ & $0.21(0.02)$ & $0.21(0.03)$ & $0.01(0.01)$ & $0.00(0.00)$ & $0.01(0.01)$ \\
\hline $\mathrm{CaO}$ & $1.29(0.09)$ & $1.23(0.07)$ & $0.38(0.04)$ & $0.26(0.05)$ & $1.34(0.04)$ & $1.34(0.08)$ & $0.38(0.05)$ & $0.37(0.03)$ & $0.21(0.03)$ \\
\hline $\mathrm{Na}_{2} \mathrm{O}$ & $5.74(0.29)$ & $5.53(0.30)$ & $5.45(0.26)$ & $5.24(0.32)$ & $5.91(0.21)$ & $5.95(0.28)$ & $5.27(0.20)$ & $5.22(0.19)$ & $6.07(0.32)$ \\
\hline $\mathrm{K}_{2} \mathrm{O}$ & $3.35(0.15)$ & $3.37(0.12)$ & $3.91(0.11)$ & $3.88(0.08)$ & $3.36(0.10)$ & $3.39(0.09)$ & $3.86(0.14)$ & $3.87(0.13)$ & $3.97(0.13)$ \\
\hline Total & 99.47 & 98.78 & 96.18 & 96.89 & 99.25 & 98.84 & 95.90 & 96.01 & 95.53 \\
\hline Q & 20.47 & 21.71 & 28.80 & 28.88 & 19.39 & 18.80 & 28.69 & 29.07 & 31.92 \\
\hline Or & 19.76 & 20.02 & 23.90 & 23.54 & 19.86 & 20.12 & 23.66 & 23.70 & 24.33 \\
\hline $\mathrm{Ab}$ & 48.49 & 47.04 & 38.48 & 39.85 & 50.04 & 50.58 & 39.25 & 38.94 & 25.32 \\
\hline An & 1.54 & 2.05 & & & 0.37 & 0.07 & & & \\
\hline $\mathrm{Ne}$ & & & & & & & & & \\
\hline $\mathrm{Di}$ & 4.26 & 3.58 & 1.74 & 1.18 & 5.52 & 5.80 & 1.74 & 1.70 & 0.96 \\
\hline $\begin{array}{l}\mathrm{Hy} \\
\mathrm{Ol}\end{array}$ & 3.27 & 3.45 & 2.97 & 3.26 & 2.63 & 2.37 & 3.09 & 3.07 & 7.38 \\
\hline Mt & 1.61 & 1.56 & & & 1.60 & 1.60 & & & \\
\hline Il & 0.55 & 0.54 & 0.33 & 0.35 & 0.53 & 0.59 & 0.30 & 0.30 & 0.49 \\
\hline Total & 99.94 & 99.94 & 99.94 & 99.94 & 99.94 & 99.94 & 99.94 & 99.94 & 99.96 \\
\hline
\end{tabular}

Notes: $*=$ ash layer sampled at two depth intervals. $\mathrm{DA}=$ dispersed ash, $\mathrm{AL}=$ ash layer. $N=$ number of analyses. $\dagger=$ number in parentheses is one standard deviation of the mean. $\mathrm{FeO}^{*}$ : total iron as $\mathrm{FeO}$. C.I.P.W. norms calculated on water-free basis with $15 \%$ total iron as $\mathrm{Fe}_{2} \mathrm{O}_{3}$ and $85 \%$ as $\mathrm{FeO}$.

1981). On such plots, the difference between volcanic systems is pronounced (Fig. 5). Basaltic glass shards from the mixed ash zone located in the uppermost $50 \mathrm{~cm}$ of Core 152-919A-1H and Core 152919B-1H (i.e., Layers A and G) show three separate fields characteristic of Grímsvötn, Veidivötn, and Katla volcanic systems on the Eastern Volcanic Zone in Iceland (Figs. 5A, B, F). These three volcanic systems have been previously proposed as the likely sources for the basaltic components of the ice-rafted ash Zone 1 in the North Atlantic and its terrestrial counterpart, the Vedde Ash in western Norway (Mangerud et al., 1984; Kvamme et al., 1989). Based on its stratigraphic position, we also suggest that this ash zone represents ash Zone 1, a Younger Dryas chronostratigraphic marker found widely in marine sediments in the North Atlantic and ${ }^{14} \mathrm{C}$ dated at $11-$ $11.1 \mathrm{ka}$ (Bard et al., 1994).

$\mathrm{TiO}_{2}$ vs. $\mathrm{K}_{2} \mathrm{O}$ plots of basaltic glass shards from the two mixed layers found between 10.2 and 11.2 mbsf in both Holes 919A and 919B (i.e., Layers B, C, H, and I) also show two separate fields with compositional ranges similar to those of Vatnafjöll and Hekla volcanic systems (Figs. 5C, D, F). The lowermost Layers $\mathrm{C}$ and I are characterized by a broader compositional range, with $\mathrm{TiO}_{2}$ content increasing with decreasing $\mathrm{K}_{2} \mathrm{O}$ content, whereas Layers $\mathrm{B}$ and $\mathrm{H}$ are more chemically homogeneous. Based on their common basaltic composition and stratigraphic position, we correlate Layers $\mathrm{B}$ and $\mathrm{C}$ in Hole 919A with Layers H and I in Hole 919B, respectively.

The only discrete basaltic layers found at Site 919 (i.e., Layer D in Hole 919A and Layer L in Hole 919B) are defined by distinct chemical fields (Fig. 5E). The Hekla and Vatnafjöll volcanic systems are the likely sources for these two tephra layers.

\section{Silicic Glass}

TAS plots of all the rhyolitic tephra recovered at Site 919 reveal a homogeneous glass composition with an Icelandic affinity (Fig. 3). Chemically homogeneous silicic tephra layers were shown to be excellent chronostratigraphic markers in both sediment cores and ice cores (Hammer, 1977; Fiacco, 1991; Palais et al., 1991, 1992; Ram and Gayley, 1991; Fiacco et al., 1993; Lacasse et al., 1995, 1996; Grönvold et al., 1995). They can be easily correlated to volcanic sources on land. Average and standard deviation of glass analyses for each rhyolitic tephra from Site 919 were calculated on a water-free basis and plot in four different chemical diagrams (i.e., $\mathrm{Al}_{2} \mathrm{O}_{3}, \mathrm{FeO} *$, $\mathrm{CaO}$, and $\mathrm{K}_{2} \mathrm{O}$ vs. $\mathrm{SiO}_{2}$ content; Fig. $6 \mathrm{~A}-\mathrm{D}$ ). These plots were compared with fields characteristic of three chronostratigraphic markers present in North Atlantic sediment, south of Iceland to $45^{\circ} \mathrm{N}$ latitude. (i.e., the ash Zones 1, 2, and 3; Sigurdsson, 1982; Lacasse et al., 1995 , 1996). These marine tephra are generally found as dispersed glass shards over depth intervals of several tens of centimeters in sediment and are interpreted to be transported and deposited by ice-rafting.

The marine ash Zone 1 was ${ }^{14} \mathrm{C}$ dated at about $11-11.1 \mathrm{ka}$ and its terrestrial counterpart, the Vedde Ash, at about 10.3-10.6 ka (Mangerud et al., 1984; Bard et al., 1994). Recent study by Lacasse et al. (1996) on the ice-rafted ash Zones 2 and 3 indicates a $\delta^{18} \mathrm{O}$ age close to 55 and $305 \mathrm{ka}$, respectively, in good agreement with previous work (Ruddiman and Glover, 1972; Smythe et al., 1985). The rhyolitic glass compositions of the tephra are chemically homogeneous and show distinct fields (Fig. 6E-F). Based on a water-free rhyolitic glass composition, ash Zone 1 and ash Zone 2 have been correlated to two major ignimbrite formations in southern Iceland-the Sólheimar Ignimbrite (Katla volcano) and the Thórsmörk Ignimbrite (Tindfjallajökull volcano) (Sigurdsson, 1982; Lacasse et al., 1995, 1996). Correlation of the tholeiitic rhyolitic ash Zone 3 with a specific Icelandic source needs further investigation.

The rhyolitic tephra recovered at Site 919 exhibit the same chemical homogeneity, with three distinct fields (Fig. 6A-D). Rhyolitic glass composition of Layers A and $\mathrm{G}$ (mixed ash zones) in Holes 919A and 919B have major element concentrations similar to that of ash Zone 1, confirming our correlation from the basaltic glass chemistry. Layers $\mathrm{A}$ and $\mathrm{G}$ have the most aluminous (13.59< $\mathrm{Al}_{2} \mathrm{O}_{3}<$ $13.70 \mathrm{wt} \%)$ and calcic $(1.25<\mathrm{CaO}<1.35 \mathrm{wt} \%)$ and, subsequently, the least siliceous $\left(71.08<\mathrm{SiO}_{2}<71.76 \mathrm{wt} \%\right)$ rhyolitic glass composition. These major element concentrations, in addition to a relatively low potassium $\left(3.37<\mathrm{K}_{2} \mathrm{O}<3.43 \mathrm{wt} \%\right)$ and high iron $(3.71<\mathrm{FeO} *$ $<3.84 \mathrm{wt} \%$ ) contents, place the silicic glass fraction of Layers A and $\mathrm{G}$ within the compositional field of transitional alkali-rhyolite. In contrast, Layers B and C in Hole 919A and Layers H and I in Hole 919B contain the most siliceous glass with $\mathrm{SiO}_{2}$ concentration ranging between 75.16 and $75.39 \mathrm{wt} \%$ (water-free basis). Variations in their alumina $\left(11.91<\mathrm{Al}_{2} \mathrm{O}_{3}<12.12 \mathrm{wt} \%\right)$, iron $\left(2.55<\mathrm{FeO}^{*}<2.58\right.$ $\mathrm{wt} \%)$, calcium $(0.27<\mathrm{CaO}<0.40 \mathrm{wt} \%)$, and potassium $\left(4.01<\mathrm{K}_{2} \mathrm{O}\right.$ $<4.07 \mathrm{wt} \%$ ) concentrations indicate an alkali-rhyolite affinity, which 
Table 3. Electron microprobe analyses of basic and intermediate glass shards from Site 919.

\begin{tabular}{|c|c|c|c|c|c|c|c|c|c|c|c|c|c|c|c|c|}
\hline Hole: & 919A & 919A & 919A & 919A & 919A & 919A & 919A & 919A & 919A & 919A & 919A & 919A & 919A & 919A & 919A & 919A \\
\hline Core, section: & $1 \mathrm{H}-1$ & $1 \mathrm{H}-1$ & $1 \mathrm{H}-1$ & $1 \mathrm{H}-1$ & $1 \mathrm{H}-1$ & $1 \mathrm{H}-1$ & $1 \mathrm{H}-1$ & $1 \mathrm{H}-1$ & $1 \mathrm{H}-1$ & $1 \mathrm{H}-1$ & $1 \mathrm{H}-1$ & $1 \mathrm{H}-1$ & $1 \mathrm{H}-1$ & $1 \mathrm{H}-1$ & $1 \mathrm{H}-1$ & $1 \mathrm{H}-1$ \\
\hline Interval: (cm) & $11-12$ & $11-12$ & $11-12$ & $11-12$ & $11-12$ & $11-12$ & $11-12$ & $11-12$ & $29-30$ & $29-30$ & $29-30$ & $29-30$ & $29-30$ & $29-30$ & $29-30$ & $29-30$ \\
\hline Layer: & $\mathrm{A}(*)$ & $\mathrm{A}(*)$ & $\mathrm{A}(*)$ & $\mathrm{A}(*)$ & $\mathrm{A}(*)$ & $\mathrm{A}(*)$ & $\mathrm{A}(*)$ & $\mathrm{A}(*)$ & $\mathrm{A}(*)$ & $\mathrm{A}(*)$ & $\mathrm{A}(*)$ & $\mathrm{A}(*)$ & $\mathrm{A}(*)$ & $\mathrm{A}(*)$ & $\mathrm{A}(*)$ & $\mathrm{A}(*)$ \\
\hline Type: & DA & DA & DA & DA & DA & DA & DA & DA & DA & DA & DA & DA & DA & DA & DA & DA \\
\hline $\mathrm{SiO}_{2}$ & 48.17 & 48.60 & 45.10 & 46.83 & 49.64 & 49.11 & 50.01 & 50.94 & 49.46 & 49.11 & 49.85 & 50.17 & 51.01 & 56.00 & 49.58 & 46.98 \\
\hline $\mathrm{TiO}_{2}$ & 4.15 & 2.38 & 4.56 & 1.45 & 3.14 & 2.90 & 2.42 & 3.95 & 1.53 & 1.45 & 1.59 & 2.70 & 1.70 & 2.97 & 4.30 & 4.54 \\
\hline $\mathrm{Al}_{2} \mathrm{O}_{3}$ & 13.03 & 13.19 & 13.40 & 16.71 & 13.61 & 13.19 & 13.18 & 13.67 & 14.94 & 15.68 & 14.64 & 13.39 & 14.12 & 13.93 & 13.35 & 13.20 \\
\hline $\mathrm{FeO} *$ & 14.43 & 13.85 & 15.44 & 9.92 & 14.41 & 14.82 & 14.32 & 13.31 & 11.53 & 11.03 & 11.63 & 14.23 & 12.49 & 11.07 & 14.77 & 15.60 \\
\hline $\mathrm{MnO}$ & 0.19 & 0.21 & 0.21 & 0.21 & 0.26 & 0.26 & 0.21 & 0.14 & 0.23 & 0.11 & 0.19 & 0.18 & 0.17 & 0.21 & 0.26 & 0.28 \\
\hline $\mathrm{MgO}$ & 4.73 & 5.80 & 5.08 & 7.87 & 5.20 & 5.60 & 5.51 & 4.22 & 8.05 & 8.14 & 7.31 & 5.46 & 6.58 & 3.40 & 4.61 & 5.06 \\
\hline $\mathrm{CaO}$ & 9.37 & 10.66 & 9.89 & 13.45 & 9.90 & 10.14 & 10.22 & 8.73 & 12.08 & 12.01 & 12.28 & 10.59 & 11.70 & 7.20 & 9.42 & 9.92 \\
\hline $\mathrm{Na}_{2} \mathrm{O}$ & 3.24 & 2.59 & 2.34 & 2.09 & 2.75 & 2.75 & 2.53 & 3.35 & 1.99 & 1.98 & 2.21 & 2.72 & 2.16 & 3.36 & 3.17 & 2.86 \\
\hline $\mathrm{K}_{2} \mathrm{O}$ & 0.86 & 0.41 & 1.68 & 0.11 & 0.48 & 0.41 & 0.31 & 1.13 & 0.16 & 0.18 & 0.24 & 0.43 & 0.29 & 1.64 & 0.81 & 0.70 \\
\hline $\mathrm{P}_{2} \mathrm{O}_{5}$ & 0.52 & 0.38 & 0.61 & 0.34 & 0.47 & 0.48 & 0.36 & 0.63 & 0.31 & 0.36 & 0.22 & 0.38 & 0.36 & 0.54 & 0.60 & 0.61 \\
\hline Total & 98.69 & 98.07 & 98.31 & 98.98 & 99.86 & 99.66 & 99.07 & 100.07 & 100.28 & 100.05 & 100.16 & 100.25 & 100.58 & 100.32 & 100.87 & 99.75 \\
\hline Hole: & 919A & $919 A$ & 919A & 919A & $919 \mathrm{~A}$ & $919 A$ & 919A & $919 \mathrm{~A}$ & 919A & 919A & 919A & 919A & 919A & 919A & 919A & 919A \\
\hline Core, section: & $1 \mathrm{H}-1$ & $1 \mathrm{H}-1$ & $1 \mathrm{H}-1$ & $1 \mathrm{H}-1$ & $2 \mathrm{H}-2$ & $2 \mathrm{H}-2$ & $2 \mathrm{H}-2$ & $2 \mathrm{H}-2$ & $2 \mathrm{H}-2$ & $2 \mathrm{H}-2$ & $2 \mathrm{H}-2$ & $2 \mathrm{H}-2$ & $2 \mathrm{H}-2$ & $2 \mathrm{H}-2$ & $2 \mathrm{H}-2$ & $2 \mathrm{H}-2$ \\
\hline Interval: (cm) & $29-30$ & $29-30$ & $29-30$ & $29-30$ & $140-141$ & $140-141$ & $140-141$ & $140-141$ & $140-141$ & $140-141$ & $140-141$ & $140-141$ & $140-141$ & $140-141$ & $140-141$ & $140-141$ \\
\hline Layer: & $\mathrm{A}(*)$ & $\mathrm{A}(*)$ & $\mathrm{A}(*)$ & $\mathrm{A}(*)$ & B & B & B & B & B & B & B & B & B & B & B & B \\
\hline Type: & $\mathrm{DA}$ & $\mathrm{DA}$ & DA & $\mathrm{DA}$ & $\mathrm{AL}$ & $\mathrm{AL}$ & $\mathrm{AL}$ & $\mathrm{AL}$ & $\mathrm{AL}$ & $\mathrm{AL}$ & $\mathrm{AL}$ & $\mathrm{AL}$ & $\mathrm{AL}$ & $\mathrm{AL}$ & $\mathrm{AL}$ & $\mathrm{AL}$ \\
\hline $\mathrm{SiO}_{2}$ & 49.85 & 48.50 & 49.01 & 50.49 & 49.79 & 50.80 & 50.20 & 50.19 & 50.83 & 49.95 & 51.05 & 50.65 & 50.94 & 50.91 & 50.56 & 50.06 \\
\hline $\mathrm{TiO}_{2}$ & 1.55 & 4.53 & 1.64 & 1.57 & 2.49 & 2.84 & 2.78 & 2.73 & 3.13 & 2.62 & 2.68 & 2.71 & 3.00 & 2.80 & 2.52 & 2.59 \\
\hline $\mathrm{Al}_{2} \mathrm{O}_{3}$ & 15.58 & 13.29 & 15.58 & 14.11 & 13.50 & 13.08 & 13.96 & 13.44 & 13.47 & 13.48 & 13.35 & 13.52 & 13.17 & 13.40 & 13.38 & 13.29 \\
\hline $\mathrm{FeO}^{*}$ & 11.30 & 14.34 & 11.44 & 12.35 & 13.83 & 15.38 & 14.34 & 14.99 & 14.71 & 13.67 & 13.36 & 14.53 & 15.04 & 14.14 & 13.60 & 13.98 \\
\hline $\mathrm{MnO}$ & 0.23 & 0.16 & 0.10 & 0.10 & 0.14 & 0.22 & 0.18 & 0.21 & 0.15 & 0.29 & 0.26 & 0.26 & 0.27 & 0.2 & 0.20 & 0.22 \\
\hline $\mathrm{MgO}$ & 8.01 & 4.70 & 8.07 & 7.08 & 5.58 & 5.31 & 5.78 & 6.51 & 5.16 & 5.7 & 5.68 & 5.36 & 5.15 & 5.28 & 5.72 & 6.83 \\
\hline $\mathrm{CaO}$ & 12.38 & 9.34 & 12.23 & 11.89 & 10.59 & 10.08 & 10.63 & 10.13 & 10.22 & 10.66 & 10.44 & 10.14 & 9.63 & 10.11 & 10.81 & 9.88 \\
\hline $\mathrm{Na}_{2} \mathrm{O}$ & 1.46 & 3.13 & 1.95 & 2.32 & 2.55 & 2.71 & 2.65 & 2.28 & 2.06 & 2.78 & 2.63 & 2.98 & 2.11 & 2.48 & 2.52 & 3.07 \\
\hline $\mathrm{K}_{2} \mathrm{O}$ & 0.14 & 0.82 & 0.24 & 0.19 & 0.38 & 0.59 & 0.56 & 0.32 & 0.45 & 0.38 & 0.39 & 0.44 & 0.45 & 0.39 & 0.33 & 0.41 \\
\hline $\mathrm{P}_{2}^{2} \mathrm{O}_{5}$ & 0.29 & 0.73 & 0.35 & 0.33 & 0.40 & 0.45 & 0.40 & 0.38 & 0.44 & 0.43 & 0.38 & 0.35 & 0.49 & 0.48 & 0.33 & 0.40 \\
\hline Total & 100.79 & 99.54 & 100.61 & 100.43 & 99.25 & 101.46 & 101.48 & 101.18 & 100.62 & 100.03 & 100.22 & 100.94 & 100.25 & 100.19 & 99.97 & 100.73 \\
\hline Iole: & 19A & 19A & 919A & 919A & $919 A$ & $919 \mathrm{~A}$ & 19A & 19A & $919 A$ & 919 & 919 & 919 & 919 & 919 & 919A & 919A \\
\hline Core, section: & $2 \mathrm{H}-2$ & $2 \mathrm{H}-2$ & $2 \mathrm{H}-2$ & $2 \mathrm{H}-3$ & $2 \mathrm{H}-3$ & $2 \mathrm{H}-3$ & $2 \mathrm{H}-3$ & $2 \mathrm{H}-3$ & $2 \mathrm{H}-3$ & $2 \mathrm{H}-3$ & $2 \mathrm{H}-3$ & $2 \mathrm{H}-3$ & $7 \mathrm{H}-4$ & $7 \mathrm{H}-4$ & $7 \mathrm{H}-4$ & $7 \mathrm{H}-4$ \\
\hline Interval $(\mathrm{cm})$ : & $140-141$ & $140-141$ & $140-141$ & $18-19$ & $18-19$ & $18-19$ & $18-19$ & $18-19$ & $18-19$ & $18-19$ & $18-19$ & $18-19$ & $135-138$ & $135-138$ & $135-138$ & $135-138$ \\
\hline Layer: & B & B & B & $\mathrm{C}$ & $\mathrm{C}$ & $\mathrm{C}$ & $\mathrm{C}$ & $\mathrm{C}$ & $\mathrm{C}$ & $\mathrm{C}$ & $\mathrm{C}$ & $\mathrm{C}$ & D & D & D & D \\
\hline Type: & $\mathrm{AL}$ & $\mathrm{AL}$ & $\mathrm{AL}$ & $\mathrm{AL}$ & $\mathrm{AL}$ & $\mathrm{AL}$ & $\mathrm{AL}$ & $\mathrm{AL}$ & $\mathrm{AL}$ & $\mathrm{AL}$ & $\mathrm{AL}$ & $\mathrm{AL}$ & $\mathrm{AL}$ & $\mathrm{AL}$ & $\mathrm{AL}$ & $\mathrm{AL}$ \\
\hline $\mathrm{SiO}_{2}$ & 50.48 & & 5 & 54.24 & & & & & & & 47.71 & 46.99 & 48.88 & 48.15 & & 47.66 \\
\hline $\mathrm{TiO}_{2}$ & 2.62 & 2.48 & 2.63 & 2.52 & 3.52 & 4.01 & 3.95 & 4.41 & 3.49 & 4.61 & 4.49 & 4.52 & 3.66 & 3.86 & 3.71 & 3.79 \\
\hline $\mathrm{Al}_{2} \mathrm{O}_{3}$ & 13.55 & 13.46 & 13.53 & 13.92 & 13.26 & 13.20 & 13.42 & 13.26 & 12.95 & 12.90 & 12.68 & 13.14 & 12.95 & 12.95 & 13.28 & 12.99 \\
\hline $\mathrm{FeO}^{*{ }^{3}}$ & 13.36 & 3.55 & 13.50 & 14.19 & 15.10 & 15.39 & 15.61 & 14.56 & 14.91 & 14.91 & 15.88 & 15.51 & 15.5 & 15.31 & 14.79 & 15.32 \\
\hline $\mathrm{MnO}$ & 0.24 & 0.25 & 0.27 & 0.16 & 0.38 & 0.25 & 0.33 & 0.31 & 0.48 & 0.32 & 0.2 & 0.23 & 0.25 & 0.12 & 0.29 & 0.39 \\
\hline $\mathrm{MgO}$ & & & & & & & & & & & & & & & 4.88 & 4.74 \\
\hline $\mathrm{CaO}$ & 11.01 & 10.51 & 10.74 & 6.99 & 8.76 & 9.34 & 9.21 & 10.05 & 8.9 & 10.01 & 9.7 & 9.81 & 9.6 & 9.53 & 9.74 & 9.36 \\
\hline $\mathrm{Na}_{2} \mathrm{O}$ & 2.35 & 2.28 & 2.97 & 3.79 & 3.60 & 3.44 & 3.27 & 2.74 & 3.29 & 2.89 & 2.89 & 3.22 & 3.10 & 2.57 & 3.01 & 2.86 \\
\hline $\mathrm{K}_{2} \mathrm{O}$ & 0.39 & 0.36 & 0.39 & 1.28 & 0.88 & 0.80 & 0.85 & 0.65 & 0.99 & 0.69 & 0.76 & 0.72 & 0.58 & 0.58 & 0.62 & 0.57 \\
\hline $\mathrm{P}_{2}^{2} \mathrm{O}_{5}$ & 0.40 & 0.42 & 0.37 & 1.25 & 1.15 & 0.92 & 1.06 & 0.96 & 1.26 & 0.90 & 0.95 & 0.96 & 0.60 & 0.55 & 0.58 & 0.52 \\
\hline Total & 100.28 & 99.41 & 100.88 & 101.07 & 101.07 & 100.98 & 101.51 & 99.59 & 101.22 & 99.35 & 100.22 & 100.05 & 100.34 & 98.64 & 98.77 & 98.20 \\
\hline Hole: & 19A & 19A & 19A & 919A & 919A & 919A & 919A & 919A & 919A & 919A & 919A & 919A & 919A & 919 & 919A & 919A \\
\hline Core, section: & $7 \mathrm{H}-4$ & $7 \mathrm{H}-4$ & $7 \mathrm{H}-4$ & $7 \mathrm{H}-4$ & $7 \mathrm{H}-4$ & $7 \mathrm{H}-4$ & $7 \mathrm{H}-4$ & $7 \mathrm{H}-4$ & $7 \mathrm{H}-4$ & $7 \mathrm{H}-4$ & $8 \mathrm{H}-1$ & $8 \mathrm{H}-1$ & $8 \mathrm{H}-1$ & $8 \mathrm{H}-1$ & $8 \mathrm{H}-1$ & $8 \mathrm{H}-1$ \\
\hline Interval $(\mathrm{cm})$ : & $135-138$ & $135-138$ & $135-138$ & $135-138$ & $135-138$ & $135-138$ & $135-138$ & $135-138$ & $135-138$ & $135-138$ & $94-95$ & $94-95$ & $94-95$ & $94-95$ & $94-95$ & $94-95$ \\
\hline Layer: & $\mathrm{D}$ & D & $\mathrm{D}$ & $\mathrm{D}$ & $\mathrm{D}$ & $\mathrm{D}$ & $\mathrm{D}$ & $\mathrm{D}$ & $\mathrm{D}$ & D & $\mathrm{E}$ & $\mathrm{E}$ & $\mathrm{E}$ & $\mathrm{E}$ & $\mathrm{E}$ & E \\
\hline Type: & $\mathrm{AL}$ & $\mathrm{AL}$ & $\mathrm{AL}$ & $\mathrm{AL}$ & $\mathrm{AL}$ & $\mathrm{AL}$ & $\mathrm{AL}$ & $\mathrm{AL}$ & $\mathrm{AL}$ & $\mathrm{AL}$ & AP & $\mathrm{AP}$ & $\mathrm{AP}$ & AP & AP & $\mathrm{AP}$ \\
\hline $\mathrm{SiO}_{2}$ & & & & & & & & & & & & & 50. & & & 48.88 \\
\hline & 3.76 & & & & & 3.97 & 3.67 & 3.66 & 3.80 & 3.91 & 2.53 & 2.62 & 3.43 & 4.29 & 4.32 & 4.03 \\
\hline $\mathrm{Al}_{2} \mathrm{O}_{3}$ & 12.89 & 14.19 & 13.05 & 13.86 & 13.17 & 13.11 & 13.23 & 13.07 & 13.04 & 12.97 & 13.91 & 13.56 & 12.94 & 12.62 & 12.91 & 12.95 \\
\hline $\mathrm{FeO}^{*{ }^{3}}$ & 5.81 & 14.81 & 15.31 & 14.16 & 15.02 & 15.54 & 15.52 & 15.55 & 14.99 & 15.41 & 13.38 & 13.29 & 14.70 & 15.27 & 14.92 & 14.62 \\
\hline $\mathrm{MnO}$ & & & & & & & & & & & 0.2 & 0.21 & 0.25 & 0.18 & 0.19 & 0.33 \\
\hline $\mathrm{MgO}$ & 4.63 & 5.98 & 4.66 & 5.26 & 4.72 & 4.73 & 4.73 & 4.79 & 4.84 & 4.80 & 6.38 & 5.89 & 4.38 & 4.41 & 4.87 & 4.75 \\
\hline $\mathrm{CaO}$ & 9.48 & 10.52 & 9.12 & 10.02 & 9.56 & 9.60 & 9.46 & 9.63 & 9.17 & 9.50 & 11.31 & 10.96 & 8.7 & 9.12 & 10.19 & 9.68 \\
\hline $\mathrm{Na}_{2} \mathrm{O}$ & 2.61 & 2.51 & 2.54 & 2.46 & 2.89 & 2.59 & 2.97 & 2.79 & 2.65 & 2.78 & 2.22 & 2.63 & 2.85 & 2.98 & 3.15 & 2.86 \\
\hline $\mathrm{K}_{2} \mathrm{O}$ & 0.62 & 0.40 & 0.62 & 0.31 & 0.60 & 0.64 & 0.65 & 0.61 & 0.56 & 0.61 & 0.23 & 0.31 & 0.72 & 0.64 & 0.78 & 0.83 \\
\hline $\mathrm{P}_{2}^{2} \mathrm{O}_{5}$ & 0.51 & 0.39 & 0.67 & 0.28 & 0.57 & 0.57 & 0.61 & 0.52 & 0.54 & 0.53 & 0.37 & 0.38 & 0.57 & 0.62 & 1.41 & 0.55 \\
\hline Total & 98.32 & 100.64 & 99.32 & 100.64 & 99.97 & 100.32 & 100.30 & 99.66 & 99.62 & 100.30 & 100.55 & 100.27 & 99.54 & 100.33 & 99.22 & 99.48 \\
\hline
\end{tabular}

matches well with that of ash Zone 2 (Fig. 6). We have correlated above the two discrete mixed ash Layers $\mathrm{H}$ and I in Hole 919B with Layers B and C in Hole 919A, respectively, based on their stratigraphic position and composition of their basaltic glass fraction. However, we can not discriminate these two chronostratigraphic markers at Site 919 from the chemistry of their rhyolitic glass fraction alone. Both rhyolitic glass compositions show a strong similarity with ash Zone 2 and likely indicate a common source in southern Iceland (i.e., the Tindfjallajökull volcano; Sigurdsson, 1982; Lacasse et al., 1996). Analyses of rhyolitic glass from the oldest silicic tephra recovered at Site 919 (i.e., Layer K [mixed ash zone]) in Hole 919B, indicate compositional ranges incompatible with any of the three previously described ash zones. Silicic glass composition of Layer $\mathrm{K}$ is characterized by the highest potassium $\left(\mathrm{K}_{2} \mathrm{O}=4.16 \pm 0.13 \mathrm{wt} \%\right)$ and iron $\left(\mathrm{FeO}^{*}=4.95 \pm 0.16 \mathrm{wt} \%\right)$ contents and the lowest calcium $(\mathrm{CaO}$ $=0.22 \pm 0.04 \mathrm{wt} \%)$ and alumina $\left(\mathrm{Al}_{2} \mathrm{O}_{3}=9.46 \pm 0.19 \mathrm{wt} \%\right)$ contents (Fig. 6A-D). Low $\mathrm{Al}_{2} \mathrm{O}_{3}$, in addition to high total alkali $\left(\mathrm{Na}_{2} \mathrm{O}+\mathrm{K}_{2} \mathrm{O}\right.$ $=10.50 \pm 0.43 \mathrm{wt} \%$ ) concentrations, classify the composition of the 
Table 3 (continued).

\begin{tabular}{|c|c|c|c|c|c|c|c|c|c|c|c|c|c|c|c|c|}
\hline Hole: & 919A & 919A & 919A & 919A & 919A & 919A & 919A & 919A & 919A & 919A & 919A & 919A & 919A & 919A & 919A & $919 \mathrm{~A}$ \\
\hline Core, section: & $8 \mathrm{H}-1$ & $8 \mathrm{H}-1$ & $8 \mathrm{H}-1$ & $8 \mathrm{H}-1$ & $8 \mathrm{H}-1$ & $8 \mathrm{H}-1$ & $8 \mathrm{H}-1$ & $8 \mathrm{H}-1$ & $8 \mathrm{H}-1$ & $8 \mathrm{H}-1$ & $10 \mathrm{H}-2$ & $10 \mathrm{H}-2$ & $10 \mathrm{H}-2$ & $10 \mathrm{H}-2$ & $10 \mathrm{H}-2$ & $10 \mathrm{H}-2$ \\
\hline Interval $(\mathrm{cm})$ : & 94-95 & 94-95 & 94-95 & 94-95 & 94-95 & 94-95 & 94-95 & 94-95 & 94-95 & 94-95 & $112-113$ & $112-113$ & $112-113$ & $112-113$ & $112-113$ & $112-113$ \\
\hline Layer: & $\mathrm{E}$ & $\mathrm{E}$ & $\mathrm{E}$ & $\mathrm{E}$ & $\mathrm{E}$ & $\mathrm{E}$ & $\mathrm{E}$ & $\mathrm{E}$ & E & $\mathrm{E}$ & F & F & F & F & F & $\mathrm{F}$ \\
\hline Type: & AP & $\mathrm{AP}$ & AP & AP & AP & AP & AP & AP & AP & AP & AP & AP & AP & AP & AP & AP \\
\hline $\mathrm{SiO}_{2}$ & 48.72 & 49.67 & 49.92 & 49.69 & 48.86 & 56.64 & 51.05 & 50.04 & 48.60 & 48.77 & 50.33 & 50.46 & 50.09 & 51.46 & 49.34 & 54.37 \\
\hline $\mathrm{TiO}_{2}^{2}$ & 3.48 & 2.95 & 2.27 & 3.43 & 3.20 & 2.17 & 3.32 & 2.67 & 3.60 & 2.77 & 2.08 & 2.42 & 2.24 & 1.66 & 3.77 & 2.91 \\
\hline $\mathrm{Al}_{2} \mathrm{O}_{3}$ & 13.51 & 13.18 & 13.71 & 13.31 & 13.52 & 14.56 & 14.63 & 12.97 & 13.69 & 13.63 & 14.42 & 13.32 & 13.31 & 14.28 & 13.45 & 13.81 \\
\hline $\mathrm{FeO}^{*}$ & 13.80 & 14.59 & 13.04 & 13.47 & 14.21 & 10.62 & 12.89 & 14.55 & 13.66 & 13.75 & 12.17 & 13.31 & 13.16 & 11.73 & 14.42 & 12.05 \\
\hline $\mathrm{MnO}$ & 0.20 & 0.19 & 0.27 & 0.28 & 0.18 & 0.19 & 0.22 & 0.25 & 0.24 & 0.30 & 0.18 & 0.23 & 0.30 & 0.21 & 0.30 & 0.18 \\
\hline $\mathrm{MgO}$ & 5.15 & 5.77 & 6.27 & 4.60 & 4.78 & 2.35 & 3.60 & 5.83 & 5.23 & 5.75 & 6.94 & 6.00 & 6.17 & 6.37 & 5.03 & 3.26 \\
\hline $\mathrm{CaO}$ & 9.78 & 10.27 & 11.30 & 9.23 & 9.24 & 5.80 & 9.25 & 10.45 & 9.88 & 10.50 & 11.81 & 11.73 & 11.72 & 11.58 & 9.59 & 7.48 \\
\hline $\mathrm{Na}_{2} \mathrm{O}$ & 2.97 & 2.72 & 2.65 & 2.79 & 2.98 & 4.23 & 3.22 & 2.55 & 3.09 & 2.71 & 2.33 & 2.13 & 2.18 & 2.00 & 2.78 & 3.88 \\
\hline $\mathrm{K}_{2} \mathrm{O}$ & 0.87 & 0.28 & 0.30 & 0.65 & 0.60 & 1.69 & 0.62 & 0.28 & 0.83 & 0.45 & 0.26 & 0.27 & 0.24 & 0.33 & 0.55 & 1.59 \\
\hline $\mathrm{P}_{2} \mathrm{O}_{5}$ & 0.70 & 0.37 & 0.31 & 0.67 & 0.53 & 0.91 & 0.58 & 0.41 & 0.58 & 0.43 & 0.40 & 0.32 & 0.39 & 0.38 & 0.58 & 0.94 \\
\hline Total & 99.18 & 99.99 & 100.04 & 98.12 & 98.10 & 99.16 & 99.38 & 100.00 & 99.40 & 99.06 & 100.92 & 100.19 & 99.80 & 100.00 & 99.81 & 100.47 \\
\hline Hole: & $919 \mathrm{~A}$ & 919A & 919A & 919A & 919A & 919A & 919A & 919A & 919A & 919B & 919B & 919B & 919B & 919B & 919B & 919B \\
\hline Core, section: & $10 \mathrm{H}-2$ & $10 \mathrm{H}-2$ & $10 \mathrm{H}-2$ & $10 \mathrm{H}-2$ & $10 \mathrm{H}-2$ & $10 \mathrm{H}-2$ & $10 \mathrm{H}-2$ & $10 \mathrm{H}-2$ & $10 \mathrm{H}-2$ & $1 \mathrm{H}-1$ & $1 \mathrm{H}-1$ & $1 \mathrm{H}-1$ & $1 \mathrm{H}-1$ & $1 \mathrm{H}-1$ & $1 \mathrm{H}-1$ & $1 \mathrm{H}-1$ \\
\hline Interval $(\mathrm{cm})$ : & $112-113$ & $112-113$ & $112-113$ & $112-113$ & $112-113$ & $112-113$ & $112-113$ & $112-113$ & $112-113$ & $24-25$ & $24-25$ & $24-25$ & $24-25$ & $24-25$ & $24-25$ & $24-25$ \\
\hline Layer: & F & F & F & $\mathrm{F}$ & $\mathrm{F}$ & $\mathrm{F}$ & F & F & $\mathrm{F}$ & $\mathrm{G}(*)$ & $\mathrm{G}(*)$ & $\mathrm{G}(*)$ & $\mathrm{G}(*)$ & $\mathrm{G}(*)$ & $\mathrm{G}(*)$ & $\mathrm{G}(*)$ \\
\hline Type: & AP & AP & AP & AP & AP & AP & AP & AP & AP & DA & $\mathrm{DA}$ & DA & DA & DA & DA & $\mathrm{DA}$ \\
\hline $\mathrm{SiO}_{2}$ & 49.80 & 50.15 & 49.60 & 47.80 & 49.26 & 50.39 & 48.88 & 48.81 & 48.80 & 48.22 & 46.87 & 48.15 & 46.30 & 49.52 & 46.66 & 49.04 \\
\hline $\mathrm{TiO}_{2}^{2}$ & 2.19 & & & 3.91 & 1.80 & 2.18 & 2.17 & 3.80 & 2.04 & 1.55 & 4.9 & 4.51 & 4.59 & 3.44 & 4.43 & 2.64 \\
\hline $\mathrm{Al}_{2} \mathrm{O}_{3}$ & 13.92 & 13.53 & 12.88 & 13.11 & 14.06 & 14.15 & 14.09 & 13.32 & 13.95 & 14.8 & 12.9 & 13.21 & 12.77 & 12.36 & 12.90 & 13.50 \\
\hline $\mathrm{FeO}^{*}$ & 13.34 & 13.70 & 15.87 & 15.21 & 12.02 & 12.15 & 12.45 & 14.71 & 12.38 & 11.58 & 14.89 & 15.00 & 15.17 & 15.70 & 14.57 & 13.68 \\
\hline $\mathrm{MnO}$ & 0.20 & 0.20 & 0.16 & 0.22 & 0.20 & 0.24 & 0.11 & 0.20 & 0.25 & 0.21 & 0.24 & 0.22 & 0.17 & 0.36 & 0.15 & 0.27 \\
\hline $\mathrm{MgO}$ & 6.65 & & 4.99 & 5.22 & & & & 4.64 & & 7.89 & & & & & 5.00 & 5.79 \\
\hline $\mathrm{CaO}$ & 11.71 & 9.77 & 9.73 & 10.02 & 11.68 & 11.24 & 11.73 & 9.41 & 11.65 & 12.26 & 9.95 & 9.46 & 10.16 & 9.73 & 10.10 & 10.72 \\
\hline $\mathrm{Na}_{2} \mathrm{O}$ & 2.55 & & 2.5 & 2.67 & 2.65 & 2.16 & 2.59 & 2.9 & 2.52 & 2.02 & 3.0 & 3.01 & 2.9 & 2.8 & 3.00 & 2.66 \\
\hline $\mathrm{K}_{2} \mathrm{O}$ & 0.18 & 0.57 & 0.37 & 0.52 & 0.24 & 0.29 & 0.21 & 0.94 & 0.22 & 0.21 & 0.7 & 0.77 & 0.68 & 0.46 & 0.75 & 0.33 \\
\hline $\mathrm{P}_{2} \mathrm{O}_{5}$ & 0.34 & 0.49 & 0.40 & 0.65 & 0.33 & 0.33 & 0.27 & 0.65 & 0.36 & 0.29 & 0.6 & 0.65 & 0.6 & 0.42 & 0.52 & 0.41 \\
\hline Total & 100.88 & 99.47 & 99.90 & 99.33 & 99.34 & 99.54 & 99.22 & 99.47 & 98.95 & 99.03 & 99.00 & 99.52 & 98.45 & 99.75 & 98.08 & 99.04 \\
\hline Hole: & $919 \mathrm{~B}$ & 919B & 919B & 919B & 919B & 919B & 919B & 919B & 919B & 919B & 919B & 919B & 919B & 919B & 919B & 919B \\
\hline Core, section: & $1 \mathrm{H}-1$ & $1 \mathrm{H}-1$ & $1 \mathrm{H}-1$ & $1 \mathrm{H}-1$ & $1 \mathrm{H}-1$ & $1 \mathrm{H}-1$ & $1 \mathrm{H}-1$ & $1 \mathrm{H}-1$ & $1 \mathrm{H}-1$ & $1 \mathrm{H}-1$ & $1 \mathrm{H}-1$ & $1 \mathrm{H}-1$ & $1 \mathrm{H}-1$ & $1 \mathrm{H}-1$ & $1 \mathrm{H}-1$ & $1 \mathrm{H}-1$ \\
\hline Interval $(\mathrm{cm})$ : & $24-25$ & $24-25$ & $24-25$ & $24-25$ & $24-25$ & $24-25$ & $24-25$ & $24-25$ & $38-39$ & $38-39$ & $38-39$ & $38-39$ & $38-39$ & $38-39$ & $38-39$ & $38-39$ \\
\hline Layer: & $\mathrm{G}(*)$ & $\mathrm{G}(*)$ & $\mathrm{G}(*)$ & $\mathrm{G}(*)$ & $\mathrm{G}(*)$ & $\mathrm{G}(*)$ & $\mathrm{G}(*)$ & $\mathrm{G}(*)$ & $\mathrm{G}(*)$ & $\mathrm{G}(*)$ & $\mathrm{G}(*)$ & $\mathrm{G}(*)$ & $\mathrm{G}(*)$ & $\mathrm{G}(*)$ & $\mathrm{G}(*)$ & $\mathrm{G}(*)$ \\
\hline Type: & DA & DA & DA & DA & $\mathrm{DA}$ & $\mathrm{DA}$ & $\mathrm{DA}$ & DA & DA & $\mathrm{DA}$ & DA & DA & DA & DA & DA & DA \\
\hline $\mathrm{SiO}_{2}$ & & & & & & & & & & & & & & & & 46.31 \\
\hline $\mathrm{TiO}_{2}^{2}$ & & & & & & & & & & & 1. & & & & 1.90 & 4.70 \\
\hline $\mathrm{Al}_{2} \mathrm{O}_{3}$ & & & & & & 14.5 & & 13. & & 13. & 14. & & & 14. & & 13.05 \\
\hline $\mathrm{FeO}$ & & & & 15.0 & & 11.7 & 13. & 14. & & 12. & 11. & 12. & & & 12. & 15.24 \\
\hline $\mathrm{Mn}$ & & & & & & & & & & 0. & & 0. & & & 0.23 & 0.27 \\
\hline $\mathrm{Mg}$ & & & & & & & & & & & & & & & & \\
\hline $\mathrm{Ca}$ & 12.21 & & & & & 11.8 & 10. & 10. & 12. & & & & & & & 9.76 \\
\hline $\mathrm{Na}_{2} \mathrm{O}$ & 1.99 & & & & 2.7 & & 2. & 2.7 & 1. & & & 2. & & & 2.42 & 2.90 \\
\hline $\mathrm{K}_{2}$ & & & & & & & & & & & & & & & 0.28 & 0.68 \\
\hline $\mathrm{P}_{2} \mathrm{O}_{5}$ & 0.35 & & & & & & 0.39 & 0.34 & & & & 0.30 & 0.27 & 0.23 & 0.31 & 0.68 \\
\hline Total & 99.96 & 100.55 & 98.79 & 99.10 & 98.82 & 99.25 & 98.80 & 99.60 & 99.47 & 99.34 & 100.08 & 100.52 & 99.84 & 99.91 & 100.13 & 98.68 \\
\hline Hole: & & & & & & & & & & 9191 & & & & & 919B & 919B \\
\hline Core, section: & $1 \mathrm{H}-1$ & $1 \mathrm{H}-1$ & $1 \mathrm{H}-1$ & $1 \mathrm{H}-1$ & $1 \mathrm{H}-1$ & $1 \mathrm{H}-1$ & $1 \mathrm{H}-1$ & $2 \mathrm{H}-1$ & $2 \mathrm{H}-1$ & $2 \mathrm{H}-1$ & $2 \mathrm{H}-1$ & $2 \mathrm{H}-1$ & $2 \mathrm{H}-1$ & $2 \mathrm{H}-1$ & $2 \mathrm{H}-1$ & $2 \mathrm{H}-1$ \\
\hline Interval $(\mathrm{cm})$ : & $38-39$ & $38-39$ & $38-39$ & $38-39$ & $38-39$ & $38-39$ & $38-39$ & 106-109 & 106-109 & $106-109$ & 106-109 & 106-109 & 106-109 & 106-109 & 106-109 & $106-109$ \\
\hline Layer: & $\mathrm{G}(*)$ & $\mathrm{G}(*)$ & $\mathrm{G}(*)$ & $\mathrm{G}(*)$ & $\mathrm{G}(*)$ & $\mathrm{G}(*)$ & $\mathrm{G}(*)$ & $\mathrm{H}$ & $\mathrm{H}$ & $\mathrm{H}$ & $\mathrm{H}$ & $\mathrm{H}$ & $\mathrm{H}$ & $\mathrm{H}$ & H & $\mathrm{H}$ \\
\hline Type: & DA & DA & DA & DA & DA & DA & DA & AL & $\mathrm{AL}$ & AL & $\mathrm{AL}$ & $\mathrm{AL}$ & $\mathrm{AL}$ & $\mathrm{AL}$ & $\mathrm{AL}$ & $\mathrm{AL}$ \\
\hline $\mathrm{SiO}_{2}$ & 45 & & & & & 51.0 & 49. & & & & & & & 49. & 49.77 & 49.22 \\
\hline & & & & & & & & & & & & & & & & \\
\hline $\mathrm{Al}_{2} \mathrm{C}$ & & & & & & 14.7 & & & & & & 13. & & & 13.78 & 13.05 \\
\hline $\mathrm{FeO}$ & 13.0 & 12.23 & & 12.7 & 13.0 & 11.6 & 11.7 & 13.7 & 13.8 & 14.7 & 13.5 & 13.8 & 14.3 & 15.21 & 13.77 & 14.59 \\
\hline $\mathrm{Mn}$ & 0. & & & & & 0.1 & & 0.3 & & 0.2 & 0.1 & $\begin{array}{r}0.21 \\
0.21\end{array}$ & 0.18 & 0.20 & 0.14 & 0.26 \\
\hline $\mathrm{Mg}$ & & & & & & & & & & & 5.5 & & & & & 5.11 \\
\hline & 11. & & & & & 11.6 & & & & & 10.3 & 10.5 & & & & 9.49 \\
\hline & & & & & & & & & & & & & & & & 2.50 \\
\hline $\mathrm{K}_{2} \mathrm{O}$ & 0.3 & & & & 1.22 & 0. & 0. & 0.4 & 0. & 0.4 & 0.3 & 0.3 & 0.4 & 0.43 & 0.35 & 0.47 \\
\hline $\mathrm{P}_{2} \mathrm{O}_{5}$ & 0.33 & 0.27 & 0.30 & 0.28 & 0.58 & 0.34 & 0.27 & 0.43 & 0.34 & 0.47 & 0.41 & 0.45 & 0.45 & 0.44 & 0.37 & 0.44 \\
\hline $\begin{array}{l}2,25 \\
\text { Total }\end{array}$ & 99.35 & 98.36 & 98.84 & 98.98 & 99.41 & 100.30 & 99.18 & 99.81 & 98.97 & 98.98 & 98.35 & 98.11 & 99.71 & 99.27 & 99.64 & 98.23 \\
\hline
\end{tabular}

rhyolitic fraction of Layer $\mathrm{K}$ into the peralkaline or comenditic group (Fig. 3). Because this important chronostratigraphic marker, located just below the Brunhes/Matuyama boundary in Hole 919B, could not be dated, further study will be necessary to correlate it with a potential source in Iceland as well as with other marine records (Fig. 2).

Normative salic components of the rhyolitic tephra of Site 919 make up between 82 (Layer K) and $92 \mathrm{wt} \%$ (Layer C) of the glasses (Table 2). As found for Site 907 (fig. 11 in Lacasse et al., in press), all the rhyolitic glasses fall within the plagioclase volume of the granite system $\mathrm{Ab}-\mathrm{Or}-\mathrm{SiO}_{2}$ for water pressure less than $1 \mathrm{~kb}$, after
Thompson and MacKenzie (1967) and Sigurdsson (1971) (Fig. 7). However, none of the transitional (Layers A and G) and alkalic rhyolitic (Layers B, C, H, and I) tephra of Site 919 plots in the orthoclase side of the diagram due to their relatively low potassium content. With increasing degree of alkalinity, they tend to plot near the limit between the low-K and high-K groups defined by Sigurdsson and Loebner (1981) but still inside the albite domain. Rhyolitic glass of Layer $\mathrm{K}$ forms a distinct compositional group that plots on the thermal minimum for water pressure of $1 \mathrm{~kb}$ and with about the same amount of normative quartz, albite, and orthoclase. This characteris- 
Table 3 (continued).

\begin{tabular}{|c|c|c|c|c|c|c|c|c|c|c|c|c|c|c|c|c|}
\hline Hole: & $919 B$ & $919 B$ & 919B & $919 B$ & $919 B$ & $919 B$ & 919B & $919 B$ & $919 B$ & $919 B$ & $919 \mathrm{~B}$ & $919 B$ & $919 \mathrm{~B}$ & $919 B$ & $919 B$ & 919B \\
\hline Core, section: & $2 \mathrm{H}-1$ & $2 \mathrm{H}-1$ & $2 \mathrm{H}-1$ & 2H-1 & $2 \mathrm{H}-2$ & $2 \mathrm{H}-2$ & $2 \mathrm{H}-2$ & $2 \mathrm{H}-2$ & $2 \mathrm{H}-2$ & $2 \mathrm{H}-2$ & $2 \mathrm{H}-2$ & $2 \mathrm{H}-2$ & $5 \mathrm{H}-5$ & $5 \mathrm{H}-5$ & $5 \mathrm{H}-5$ & $5 \mathrm{H}-5$ \\
\hline Interval $(\mathrm{cm})$ : & $106-109$ & $106-109$ & $106-109$ & $106-109$ & $24-27$ & $24-27$ & $24-27$ & $24-27$ & $24-27$ & $24-27$ & $24-27$ & $24-27$ & $87-88$ & $87-88$ & $87-88$ & $87-88$ \\
\hline Layer: & $\mathrm{H}$ & $\mathrm{H}$ & $\mathrm{H}$ & $\mathrm{H}$ & I & I & I & I & I & I & I & I & $\mathrm{J}$ & $\mathrm{J}$ & $\mathrm{J}$ & $\mathrm{J}$ \\
\hline Type: & $\mathrm{AL}$ & $\mathrm{AL}$ & $\mathrm{AL}$ & $\mathrm{AL}$ & $\mathrm{AL}$ & $\mathrm{AL}$ & $\mathrm{AL}$ & $\mathrm{AL}$ & $\mathrm{AL}$ & $\mathrm{AL}$ & $\mathrm{AL}$ & $\mathrm{AL}$ & $\mathrm{AP}$ & $\mathrm{AP}$ & $\mathrm{AP}$ & $\mathrm{AP}$ \\
\hline $\mathrm{SiO}_{2}$ & 49.41 & 49.76 & 49.92 & 49.95 & 60.12 & 46.46 & 46.22 & 60.05 & 45.71 & 47.81 & 49.47 & 52.26 & 48.95 & 49.80 & 50.12 & 49.74 \\
\hline $\mathrm{TiO}_{2}$ & 2.71 & 3.18 & 3.29 & 3.19 & 1.25 & 4.70 & 4.63 & 1.06 & 4.63 & 4.01 & 3.46 & 3.29 & 3.77 & 3.66 & 3.80 & 3.81 \\
\hline $\mathrm{Al}_{2} \mathrm{O}_{3}$ & 13.63 & 13.47 & 13.71 & 13.19 & 12.86 & 13.09 & 13.06 & 12.83 & 12.85 & 13.16 & 12.99 & 13.16 & 12.52 & 13.11 & 12.18 & 12.43 \\
\hline $\mathrm{FeO}^{* 3}$ & 13.41 & 15.00 & 14.64 & 14.47 & 13.32 & 15.61 & 15.34 & 11.53 & 15.70 & 15.15 & 14.86 & 13.74 & 16.29 & 14.43 & 15.79 & 15.51 \\
\hline $\mathrm{MnO}$ & 0.13 & 0.31 & 0.18 & 0.20 & 0.43 & 0.20 & 0.23 & 0.50 & 0.39 & 0.23 & 0.33 & 0.39 & 0.16 & 0.14 & 0.22 & 0.28 \\
\hline $\mathrm{MgO}$ & 5.66 & 5.06 & 5.16 & 5.02 & 0.93 & 4.90 & 4.86 & 0.46 & 4.91 & 4.54 & 3.84 & 3.40 & 4.69 & 4.69 & 4.39 & 4.50 \\
\hline $\mathrm{CaO}$ & 10.35 & 9.61 & 9.81 & 9.69 & 5.05 & 10.03 & 9.88 & 4.23 & 9.99 & 9.33 & 8.15 & 7.48 & 9.29 & 9.13 & 8.93 & 9.10 \\
\hline $\mathrm{Na}_{2} \mathrm{O}$ & 2.71 & 2.79 & 2.76 & 2.43 & 4.28 & 3.09 & 3.18 & 3.93 & 3.09 & 3.38 & 3.29 & 3.00 & 2.66 & 2.98 & 2.85 & 2.80 \\
\hline $\mathrm{K}_{2} \mathrm{O}$ & 0.41 & 0.41 & 0.42 & 0.39 & 1.67 & 0.68 & 0.63 & 1.71 & 0.65 & 0.80 & 0.91 & 1.29 & 0.57 & 0.56 & 0.65 & 0.58 \\
\hline $\mathrm{P}_{2} \mathrm{O}_{5}$ & 0.44 & 0.44 & 0.43 & 0.44 & 0.49 & 0.98 & 0.96 & 0.32 & 1.03 & 1.01 & 1.20 & 0.94 & 0.70 & 0.45 & 0.73 & 0.69 \\
\hline Total & 98.86 & 100.03 & 100.32 & 98.97 & 99.74 & 99.74 & 98.99 & 96.62 & 98.95 & 99.42 & 98.50 & 98.95 & 99.60 & 98.95 & 99.66 & 99.44 \\
\hline Hole: & 919B & 919B & 919B & 919B & 919B & 919B & 919B & 919B & 919B & 919B & 919B & 919B & 919B & 919B & $919 B$ & 919B \\
\hline Core, section: & $5 \mathrm{H}-5$ & $5 \mathrm{H}-5$ & $5 \mathrm{H}-5$ & $5 \mathrm{H}-5$ & $5 \mathrm{H}-5$ & $5 \mathrm{H}-5$ & $5 \mathrm{H}-5$ & $5 \mathrm{H}-5$ & $5 \mathrm{H}-5$ & $6 \mathrm{H}-6$ & $6 \mathrm{H}-6$ & $6 \mathrm{H}-6$ & $6 \mathrm{H}-6$ & $6 \mathrm{H}-6$ & $6 \mathrm{H}-6$ & $6 \mathrm{H}-6$ \\
\hline Interval $(\mathrm{cm})$ : & $87-88$ & $87-88$ & $87-88$ & $87-88$ & $87-88$ & $87-88$ & $87-88$ & $87-88$ & $87-88$ & $22-25$ & $22-25$ & $22-25$ & $22-25$ & $87-91$ & $87-91$ & $87-91$ \\
\hline Layer: & $\mathrm{J}$ & $\mathrm{J}$ & J & J & J & J & J & J & J & K & K & K & K & L & $\mathrm{L}$ & $\mathrm{L}$ \\
\hline Type: & $\mathrm{AP}$ & AP & $\mathrm{AP}$ & $\mathrm{AP}$ & $\mathrm{AP}$ & $\mathrm{AP}$ & $\mathrm{AP}$ & $\mathrm{AP}$ & $\mathrm{AP}$ & DA & DA & DA & DA & $\mathrm{AL}$ & $\mathrm{AL}$ & $\mathrm{AL}$ \\
\hline $\mathrm{SiO}_{2}$ & 49.60 & 49.65 & 49.04 & 48.64 & 49.62 & 48.82 & 48.55 & 48.86 & 48.88 & 50.43 & 51.78 & 51.24 & 50.73 & 49.71 & 50.46 & 49.97 \\
\hline $\mathrm{TiO}_{2}$ & 3.94 & 3.75 & 3.78 & 3.74 & 3.93 & 3.78 & 3.69 & 4.04 & 3.78 & 2.41 & 3.42 & 2.37 & 3.75 & 2.96 & 3.25 & 3.07 \\
\hline $\mathrm{Al}_{2} \mathrm{O}_{3}$ & 12.35 & 12.38 & 12.18 & 12.07 & 12.65 & 12.01 & 12.32 & 12.45 & 12.46 & 13.27 & 12.99 & 13.40 & 12.85 & 13.12 & 12.60 & 13.19 \\
\hline $\mathrm{FeO}^{* 3}$ & 15.52 & 15.78 & 15.72 & 16.38 & 14.50 & 16.02 & 16.11 & 16.12 & 15.59 & 14.26 & 14.37 & 14.38 & 14.76 & 14.94 & 15.43 & 15.17 \\
\hline $\mathrm{MnO}$ & 0.23 & 0.19 & 0.34 & 0.24 & 0.22 & 0.27 & 0.30 & 0.23 & 0.16 & 0.42 & 0.27 & 0.27 & 0.13 & 0.23 & 0.27 & 0.31 \\
\hline $\mathrm{MgO}$ & 4.36 & 4.52 & 4.42 & 4.69 & 4.66 & 4.57 & 4.56 & 4.68 & 4.59 & 5.81 & 4.79 & 5.69 & 4.54 & 5.12 & 4.56 & 4.90 \\
\hline $\mathrm{CaO}$ & 8.97 & 9.08 & 9.60 & 9.08 & 8.98 & 9.02 & 9.27 & 9.19 & 9.27 & 10.86 & 9.20 & 10.51 & 9.32 & 9.88 & 9.44 & 9.68 \\
\hline $\mathrm{Na}_{2} \mathrm{O}$ & 2.71 & 2.80 & 2.48 & 2.83 & 2.98 & 2.74 & 2.64 & 2.69 & 2.71 & 2.51 & 2.78 & 2.63 & 2.77 & 1.81 & 2.70 & 2.72 \\
\hline $\mathrm{K}_{2} \mathrm{O}$ & 0.59 & 0.54 & 0.56 & 0.57 & 0.45 & 0.60 & 0.57 & 0.59 & 0.65 & 0.21 & 0.66 & 0.34 & 0.61 & 0.31 & 0.44 & 0.40 \\
\hline $\mathrm{P}_{2} \mathrm{O}_{5}$ & 0.74 & 0.72 & 0.73 & 0.72 & 0.59 & 0.62 & 0.68 & 0.70 & 0.73 & 0.39 & 0.56 & 0.43 & 0.62 & 0.45 & 0.53 & 0.42 \\
\hline Total & 99.01 & 99.41 & 98.85 & 98.96 & 98.58 & 98.45 & 98.69 & 99.55 & 98.82 & 100.57 & 100.82 & 101.26 & 100.08 & 98.53 & 99.68 & 99.83 \\
\hline Hole: & 919B & 919B & 919B & 919B & 919B & 919B & 919B & 919B & 919B & 919B & 919B & 919B & 919B & 919B & 919B & 919B \\
\hline Core, section: & $6 \mathrm{H}-6$ & $6 \mathrm{H}-6$ & $6 \mathrm{H}-6$ & $6 \mathrm{H}-6$ & $6 \mathrm{H}-6$ & $6 \mathrm{H}-6$ & $6 \mathrm{H}-6$ & $6 \mathrm{H}-6$ & $6 \mathrm{H}-6$ & $6 \mathrm{H}-6$ & $6 \mathrm{H}-6$ & $6 \mathrm{H}-6$ & $8 \mathrm{H}-3$ & $8 \mathrm{H}-3$ & $8 \mathrm{H}-3$ & $8 \mathrm{H}-3$ \\
\hline Interval $(\mathrm{cm})$ : & $87-91$ & $87-91$ & $87-91$ & $87-91$ & $87-91$ & $87-91$ & $87-91$ & $87-91$ & $87-91$ & $87-91$ & $87-91$ & $87-91$ & 94-95 & $94-95$ & $94-95$ & 94-95 \\
\hline Layer: & $\mathrm{L}$ & $\mathrm{L}$ & $\mathrm{L}$ & $\mathrm{L}$ & $\mathrm{L}$ & L & $\mathrm{L}$ & $\mathrm{L}$ & $\mathrm{L}$ & $\mathrm{L}$ & $\mathrm{L}$ & $\mathrm{L}$ & M & M & M & M \\
\hline Type: & $\overline{A L}$ & $\overline{A L}$ & $\overline{\mathrm{AL}}$ & $\mathrm{AL}$ & $\overline{A L}$ & $\overline{\mathrm{AL}}$ & $\overline{\mathrm{AL}}$ & $\overline{\mathrm{AL}}$ & $\overline{\mathrm{AL}}$ & $\overline{\mathrm{AL}}$ & $\overline{\mathrm{AL}}$ & $\overline{\mathrm{AL}}$ & $\mathrm{AP}$ & $\mathrm{AP}$ & $\mathrm{AP}$ & $\mathrm{AP}$ \\
\hline $\mathrm{SiO}_{2}$ & 50.41 & 54.15 & 50.20 & 50.06 & 49.27 & 48.82 & 49.05 & 48.59 & 49.30 & 49.63 & 49.53 & 50.40 & 48.16 & 49.17 & 50.68 & 50.36 \\
\hline $\mathrm{TiO}_{2}$ & 3.05 & 2.74 & 2.99 & 3.08 & 3.08 & 2.99 & 3.21 & 2.99 & 2.28 & 2.98 & 3.47 & 3.11 & 1.84 & 2.59 & 1.72 & 2.62 \\
\hline $\mathrm{Al}_{2} \mathrm{O}_{3}$ & 12.82 & 12.90 & 12.58 & 12.56 & 12.96 & 13.04 & 12.72 & 13.24 & 13.43 & 13.26 & 12.97 & 13.26 & 15.23 & 14.06 & 13.68 & 13.89 \\
\hline $\mathrm{FeO}^{*^{*}}$ & 15.48 & 13.79 & 15.05 & 15.24 & 14.86 & 14.85 & 15.41 & 15.07 & 13.84 & 14.72 & 14.90 & 15.20 & 11.53 & 13.91 & 13.81 & 14.14 \\
\hline $\mathrm{MnO}$ & 0.19 & 0.16 & 0.30 & 0.16 & 0.23 & 0.27 & 0.21 & 0.24 & 0.22 & 0.17 & 0.25 & 0.23 & 0.29 & 0.24 & 0.12 & 0.26 \\
\hline $\mathrm{MgO}$ & 4.98 & 3.93 & 4.96 & 5.02 & 4.88 & 5.08 & 4.93 & 5.34 & 6.28 & 5.06 & 5.17 & 5.26 & 7.75 & 6.27 & 5.94 & 5.86 \\
\hline $\mathrm{CaO}$ & 9.55 & 8.24 & 9.84 & 9.37 & 9.74 & 9.91 & 9.41 & 9.65 & 11.25 & 9.59 & 9.75 & 9.73 & 12.38 & 11.08 & 10.63 & 10.24 \\
\hline $\mathrm{Na}_{2} \mathrm{O}$ & 2.82 & 2.84 & 2.93 & 2.76 & 2.86 & 2.74 & 2.73 & 2.88 & 2.48 & 2.82 & 2.57 & 2.98 & 2.28 & 2.40 & 2.31 & 2.62 \\
\hline $\mathrm{K}_{2} \mathrm{O}$ & 0.37 & 0.88 & 0.40 & 0.39 & 0.37 & 0.38 & 0.44 & 0.41 & 0.27 & 0.40 & 0.42 & 0.40 & 0.19 & 0.31 & 0.27 & 0.26 \\
\hline $\mathrm{P}_{2} \mathrm{O}_{5}$ & 0.48 & 0.42 & 0.40 & 0.45 & 0.43 & 0.35 & 0.44 & 0.44 & 0.45 & 0.47 & 0.45 & 0.48 & 0.40 & 0.40 & 0.31 & 0.41 \\
\hline Total & 100.15 & 100.05 & 99.65 & 99.09 & 98.68 & 98.43 & 98.55 & 98.85 & 99.80 & 99.10 & 99.48 & 101.05 & 100.05 & 100.43 & 99.47 & 100.66 \\
\hline Hole: & 919B & $919 B$ & 919B & $919 \mathrm{~B}$ & $919 B$ & $919 B$ & $919 \mathrm{~B}$ & $919 B$ & $919 \mathrm{~B}$ & & & & & & & \\
\hline Core, section: & $8 \mathrm{H}-3$ & $8 \mathrm{H}-3$ & $8 \mathrm{H}-3$ & $8 \mathrm{H}-3$ & $8 \mathrm{H}-3$ & $8 \mathrm{H}-3$ & $8 \mathrm{H}-3$ & $8 \mathrm{H}-3$ & $8 \mathrm{H}-3$ & & & & & & & \\
\hline Interval $(\mathrm{cm})$ : & $94-95$ & $94-95$ & $94-95$ & $94-95$ & $94-95$ & $94-95$ & 94-95 & $94-95$ & $94-95$ & & & & & & & \\
\hline Layer: & M & M & M & M & M & M & M & M & M & & & & & & & \\
\hline Type: & $\mathrm{AP}$ & $\mathrm{AP}$ & $\mathrm{AP}$ & $\mathrm{AP}$ & $\mathrm{AP}$ & $\mathrm{AP}$ & $\mathrm{AP}$ & $\mathrm{AP}$ & AP & & & & & & & \\
\hline $\mathrm{SiO}_{2}$ & 50.69 & 51.36 & 51.63 & 51.33 & 50.64 & 50.01 & 49.23 & 50.61 & 50.69 & & & & & & & \\
\hline $\mathrm{TiO}_{2}$ & 1.50 & 1.75 & 1.48 & 1.54 & 1.65 & 3.65 & 2.06 & 1.70 & 1.85 & & & & & & & \\
\hline $\mathrm{Al}_{2} \mathrm{O}_{3}$ & 14.47 & 13.67 & 14.08 & 13.77 & 13.61 & 12.80 & 13.68 & 13.79 & 14.02 & & & & & & & \\
\hline $\mathrm{FeO}^{*}$ & 11.77 & 13.63 & 12.84 & 12.72 & 12.92 & 15.05 & 15.26 & 13.63 & 11.83 & & & & & & & \\
\hline $\mathrm{MnO}$ & 0.27 & 0.22 & 0.14 & 0.24 & 0.28 & 0.25 & 0.25 & 0.22 & 0.27 & & & & & & & \\
\hline $\mathrm{MgO}$ & 7.12 & 6.26 & 6.42 & 6.52 & 6.35 & 4.19 & 5.80 & 6.29 & 6.70 & & & & & & & \\
\hline $\mathrm{CaO}$ & 12.09 & 10.91 & 11.54 & 11.21 & 10.60 & 8.76 & 10.44 & 11.02 & 11.12 & & & & & & & \\
\hline $\mathrm{Na}_{2} \mathrm{O}$ & 1.99 & 2.21 & 2.24 & 2.19 & 2.26 & 3.10 & 2.30 & 2.13 & 2.62 & & & & & & & \\
\hline $\mathrm{K}_{2} \mathrm{O}$ & 0.10 & 0.16 & 0.18 & 0.17 & 0.24 & 0.76 & 0.14 & 0.23 & 0.15 & & & & & & & \\
\hline $\mathrm{P}_{2} \mathrm{O}_{5}$ & 0.32 & 0.32 & 0.28 & 0.34 & 0.33 & 0.75 & 0.36 & 0.33 & 0.38 & & & & & & & \\
\hline Total & 100.32 & 100.49 & 100.83 & 100.03 & 98.88 & 99.32 & 99.52 & 99.95 & 99.63 & & & & & & & \\
\hline
\end{tabular}

Notes: $*$ ash layer sampled at two depth intervals. $\mathrm{DA}=$ dispersed ash, $\mathrm{AL}=$ ash layer, and $\mathrm{AP}=$ ash pod. $\mathrm{FeO} *=$ total iron as $\mathrm{FeO}$.

tic appears to be common of comenditic glass compositions as found for Site 907 tephra (Lacasse et al., in press).

\section{Trace Elements}

Six tephra samples were analyzed by neutron activation for their trace element concentration (Table 4). Neither crystal-rich ash zones, nor material available in low amounts, were analyzed. As analyses were carried out on bulk ash samples, the concentration diagrams for mixed tephra consequently reflect the bulk composition, including the different amounts of mafic and silicic glass. Rare earth element (REE) concentrations ( $\mathrm{ppm}$ ) were normalized to the mean chondritic C1 composition of Anders and Grevesse (1989) and compared to the REE patterns of basic and silicic rocks from Iceland and Jan Mayen (Fig. 8). REE spectra of dominantly rhyolitic tephra layers (C, I, and $\mathrm{K})$ show a pronounced enrichment in light rare earth elements 


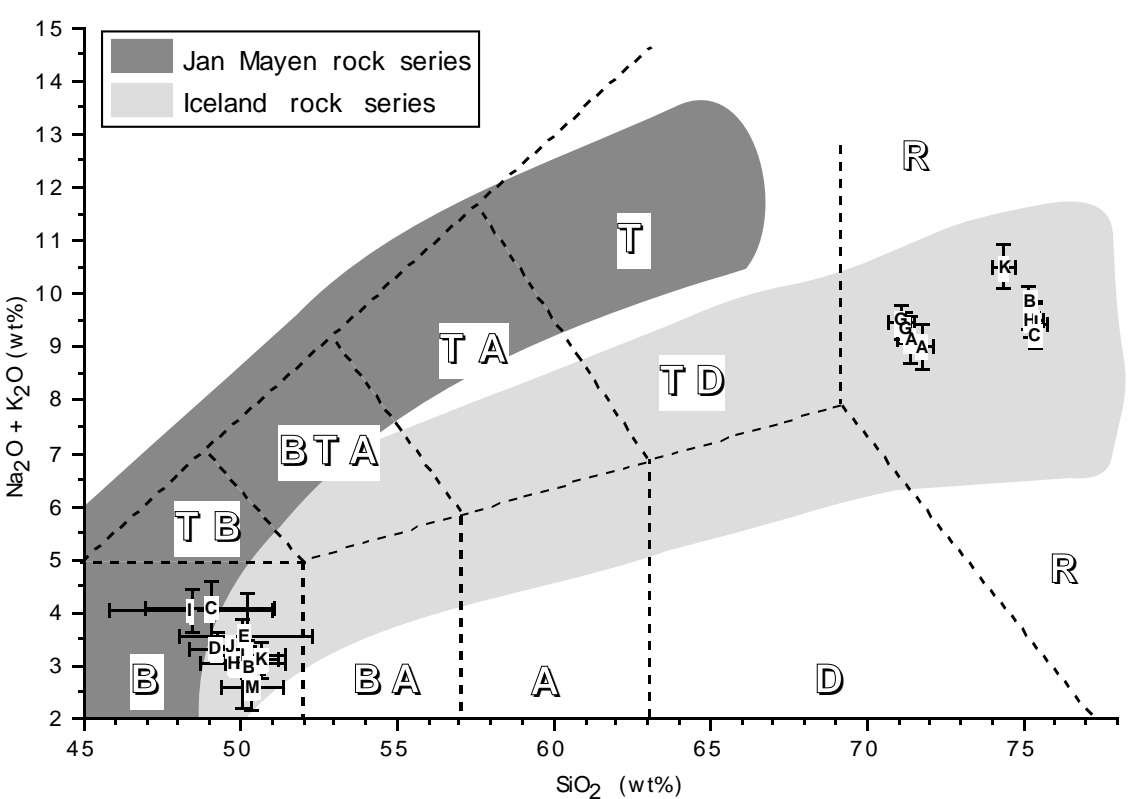

Figure 3. Total alkali-silica (TAS) plot indicating classification (after Le Bas et al., 1986), on an anhydrous basis, of glass shards (mean and standard deviation) from Site 919, Irminger Basin. Fields: B = basalt; BA = basaltic andesite; $\mathrm{A}=$ andesite $\mathrm{D}=$ dacite $\mathrm{R}=$ rhyolite $\mathrm{TD}=$ trachydacite $\mathrm{T}=$ trachyte $\mathrm{TA}=$ trachyandesite; $\mathrm{BTA}=$ basaltic trachyandesite; and $\mathrm{TB}=$ trachybasalt. All analyses have been normalized to a total of $100 \%$. Fields for Jan Mayen and Iceland rock suites (whole-rock composition) are from Imsland (1984) and Jakobsson (1979a), respectively.
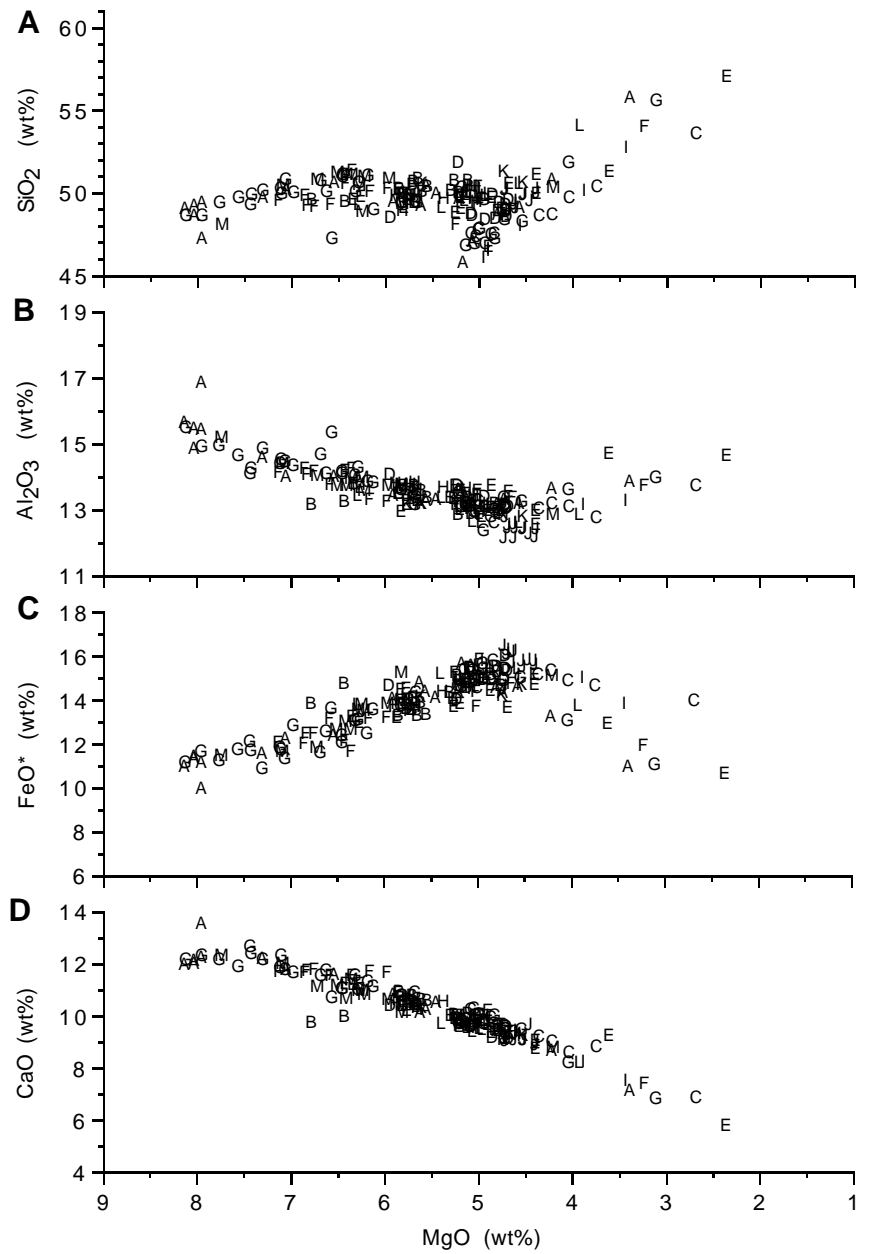

Figure 4. Fields of basaltic and basaltic andesitic glasses from PliocenePleistocene tephra in cores from Holes $919 \mathrm{~A}$ and $919 \mathrm{~B}$ in (A) $\mathrm{SiO}_{2} / \mathrm{MgO}$, (B) $\mathrm{Al}_{2} \mathrm{O}_{3} / \mathrm{MgO}$, (C) $\mathrm{FeO} * / \mathrm{MgO}$, and (D) $\mathrm{CaO} / \mathrm{MgO}$ diagrams. Plots are vs. decreasing $\mathrm{MgO}$ concentration. All analyses have been normalized to a total of $100 \%$.
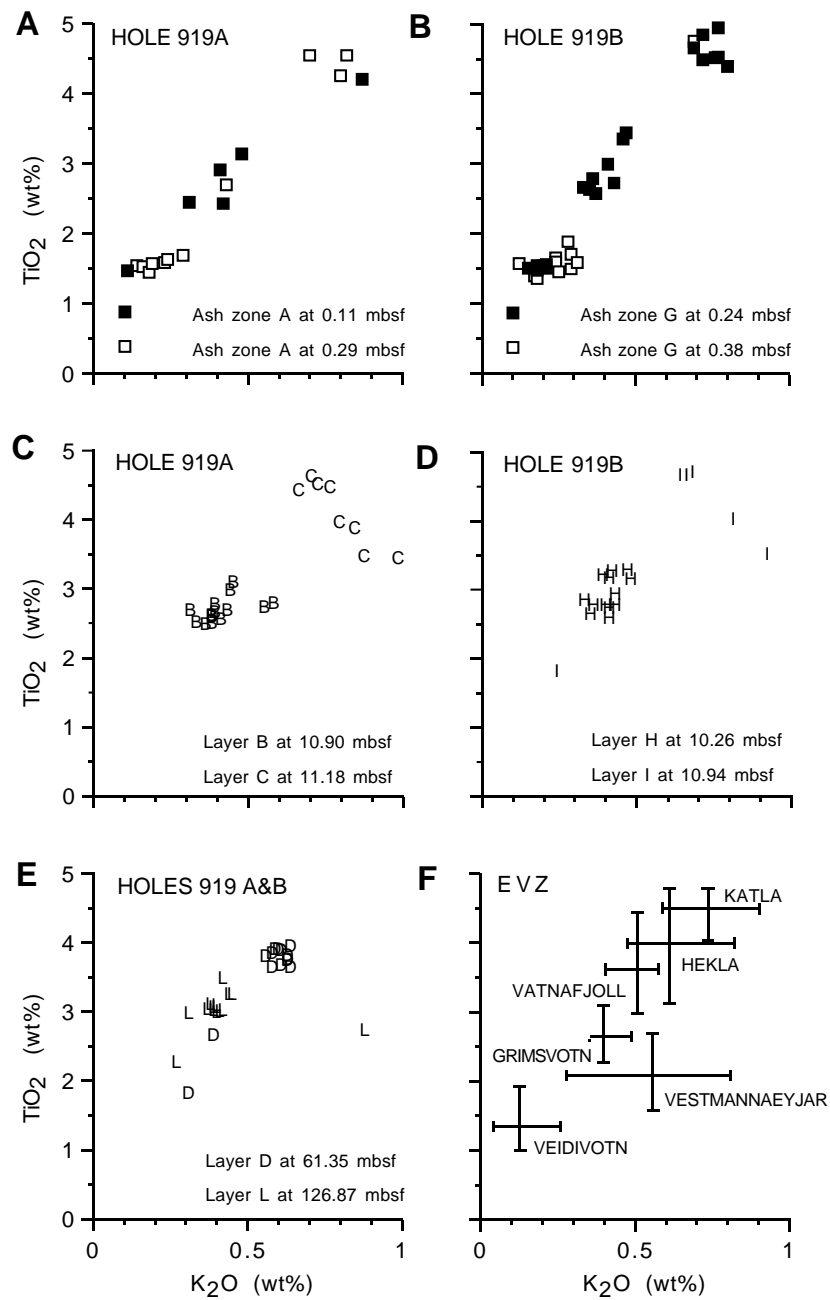

Figure 5. A-E. $\mathrm{TiO}_{2} / \mathrm{K}_{2} \mathrm{O}$ plots for basaltic and basaltic andesitic glasses from Pliocene-Pleistocene tephra in cores from Hole 919A and 919B. All analyses have been normalized to a total of $100 \%$. F. Fields for the Eastern Volcanic Zone (EVZ) in Iceland after Jakobsson (1979b) and Larsen (1981). 
Figure 6. Fields of rhyolitic glasses (mean and standard deviation) from Pliocene-Pleistocene tephra in cores from Holes 919A and 919B in (A) $\mathrm{Al}_{2} \mathrm{O}_{3} / \mathrm{SiO}_{2},(\mathbf{B})$ $\mathrm{FeO} * / \mathrm{SiO}_{2}$, (C) $\mathrm{CaO} / \mathrm{SiO}_{2}$, and (D) $\mathrm{K}_{2} \mathrm{O} / \mathrm{SiO}_{2}$ diagrams. $\mathbf{E}-\mathbf{H}$. Fields of rhyolitic glasses from ash Zones 1,2 , and 3 in cores SU9029, SU9032, and K708 (after Lacasse et al., 1996). All analyses have been normalized to a total of $100 \%$.

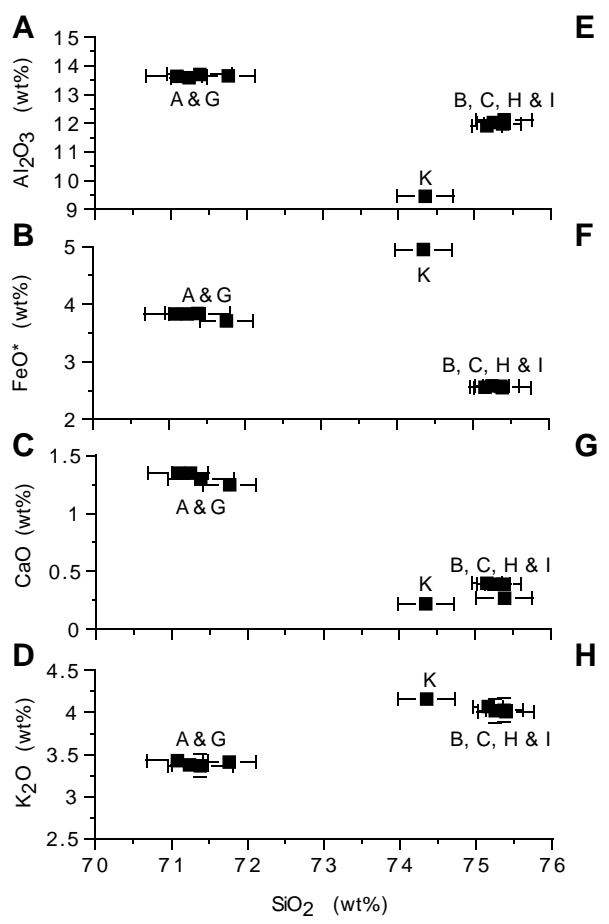

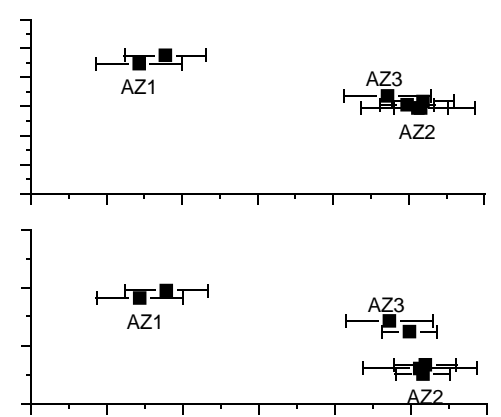
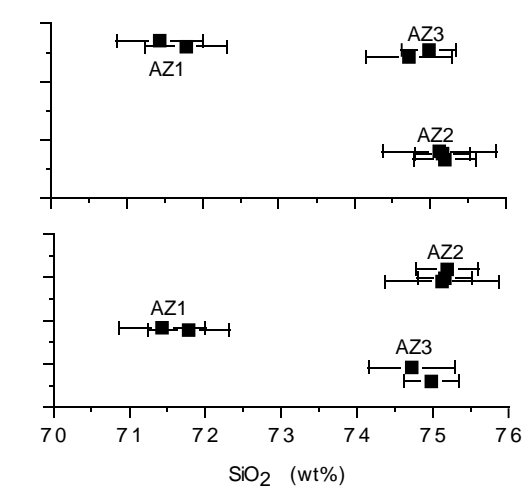

(LREE) and depletion in Eu as for the silicic rocks in Iceland. Layer C in Hole 919A has been previously correlated with Layer I in Hole 919B based on the major element concentration of their basaltic and rhyolitic glass fractions. Both present an identical REE pattern, which indicates a similar amount of basaltic glass (minor fraction) and rhyolitic glass shards (dominant fraction). In contrast, correlative Layer B (Hole 919A) and Layer H (Hole 919B) are characterized by a limited enrichment in LREE due to the abundance of basaltic over rhyolitic glass shards. The slight LREE-enriched character of the basaltic Layer L reflects an evolved basaltic composition.

\section{DISCUSSION}

From the temporal distribution of ash layers at Site 919 we can infer several episodes of tephra deposition in the Irminger Basin, approximately $200 \mathrm{~km}$ off the East Greenland coast, during the Pliocene-Pleistocene period. Correlation between marine and terrestrial records (ice cores) in Greenland can also be attempted, for longrange transport of Icelandic tephra over a distance of at least $750 \mathrm{~km}$ from source (Fig. 1). Processes responsible for the widespread dispersal of tephra from Iceland to the Irminger Basin include: airborne transport, turbidity currents, and ice-rafting. However, only airborne dispersal of tephra by easterly winds can lead to their fallout both on the Greenland ice cap and in marine sediments in the Irminger Basin. Modal and granulometric characteristics of the discrete ash layers of Site 919 (type AL in Table 1), and their distance from Iceland suggest that they were derived from large explosive eruptions with plumes reaching the stratosphere.

The atmospheric circulation above Iceland is almost entirely from west to east at the tropopause $(8-11 \mathrm{~km}$ elevation) and in the lower part of the stratosphere (Craig, 1965; Palmen, 1969), and this has lead to the dispersal of tephra east and north of Iceland during at least the Holocene and present (Thórarinsson, 1967; Kellogg, 1973; Sparks et al., 1981; Sejrup et al., 1989; Sjølholm et al., 1991). Wind velocities between $15-30 \mathrm{~m} / \mathrm{s}$ at $10 \mathrm{~km}$ and $100 \mathrm{~m} / \mathrm{s}$ higher in the stratosphere are commonly recorded (Craig, 1965; Palmen, 1969). The recovery of numerous ash falls at Site 907, on the Iceland Plateau, about 350 $\mathrm{km}$ north of Iceland, indicates that westerly and southwesterly winds influenced the dispersal of tephra during at least the Pliocene-

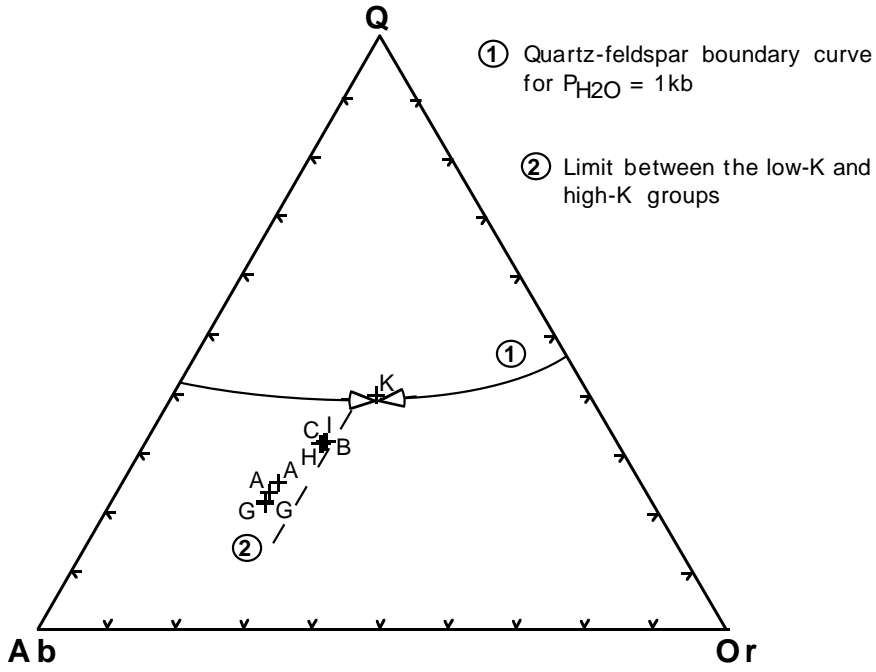

Figure 7. Normative projection of rhyolitic tephra from Site 919 in the "granite" system. The quartz-feldspar boundary curve is for $\mathrm{P}_{\mathrm{H} 2 \mathrm{O}}=1 \mathrm{~kb}$ (after Thompson and MacKenzie, 1967; Sigurdsson, 1971). Dashed line indicates the limit between the low-K and high-K groups (after Sigurdsson and Loebner, 1981).

Pleistocene (Lacasse et al., in press). The middle and upper Pleistocene is characterized by a relatively steady deposition of ash layers and ash zones in this region with the exception of a period between isotopic Stages 15 and $8(620-245 \mathrm{ka})$ where the sediment is devoid of ash deposition. In addition to a possible decrease in the volcanic activity, two hypotheses were suggested to explain the lack of tephra north and east of Iceland during this period: the occurrence of dense pack-ice or a modification in the stratospheric wind patterns (intensity and direction).

Both of these environmental factors are strongly sensitive to seasonal and long-term climatic fluctuations and may have influenced the deep-sea deposition of airborne tephra at Site 919 as well. Due to the great distance of this site from Iceland $(750 \mathrm{~km})$, only the major 
Table 4. Trace element analyses (ppm) of bulk ash layers from Site 919 by neutron activation (INAA).

\begin{tabular}{|c|c|c|c|c|c|c|c|c|c|}
\hline Hole: & 919A & 919A & 919B & 919B & 919B & 919B & $907 \mathrm{~A}$ & $907 \mathrm{~A}$ & $907 \mathrm{~A}$ \\
\hline Core, section: & $2 \mathrm{H}-2$ & $2 \mathrm{H}-3$ & $2 \mathrm{H}-1$ & $2 \mathrm{H}-2$ & $6 \mathrm{H}-6$ & $6 \mathrm{H}-6$ & $9 \mathrm{H}-6$ & $10 \mathrm{H}-1$ & $10 \mathrm{H}-2$ \\
\hline Interval $(\mathrm{cm})$ : & $140-141$ & $18-19$ & $106-109$ & $24-27$ & $22-25$ & $87-91$ & $115-117$ & $148-150$ & $0-2$ \\
\hline Layer: & B & $\mathrm{C}$ & $\mathrm{H}$ & I & K & $\mathrm{L}$ & $\mathrm{AB}$ & $\mathrm{AC}(*)$ & $\mathrm{AC}(*)$ \\
\hline $\mathrm{Rb}$ & 9.8 & 94 & 19 & 88 & 110 & 18 & 65 & 39 & \\
\hline Cs & & 1.2 & 0.2 & 1 & 1 & 0.14 & 0.61 & 0.38 & 0.3 \\
\hline $\mathrm{Br}$ & & 7.2 & & 6.1 & 3.3 & & 0.86 & 1.2 & 0.74 \\
\hline $\mathrm{Cr}$ & 4.8 & 8 & 54 & 23 & 38 & 51 & 10 & 11 & 8.2 \\
\hline Co & 39 & 3.2 & 40 & 5.7 & 4.6 & 38 & 4.2 & 7.7 & 7.1 \\
\hline $\mathrm{Ni}$ & & & 42 & 20 & 15 & & & 24 & 20 \\
\hline As & & 2.2 & & 1.6 & & & $<1.7$ & 2.7 & 2.9 \\
\hline $\mathrm{Se}$ & 1.6 & 15 & 1.8 & 140 & & 2.7 & 4.9 & 6.8 & 5.8 \\
\hline $\mathrm{Sr}$ & 110 & $<50$ & 130 & 94 & & 170 & 39 & 110 & 97 \\
\hline $\mathrm{Zr}$ & 130 & 930 & 250 & 800 & 800 & 180 & 220 & 510 & 470 \\
\hline $\mathrm{Sb}$ & & 0.78 & 0.38 & 0.28 & 1.2 & 0.61 & 0.26 & 0.24 & 0.2 \\
\hline $\mathrm{Ba}$ & 93 & 370 & 90 & 380 & 140 & 120 & 370 & 310 & 270 \\
\hline $\mathrm{Sc}$ & 35 & 2.6 & 35 & 5.9 & 5 & 34 & 6.3 & 9.4 & 8.5 \\
\hline $\mathrm{La}$ & 13 & 110 & 15 & 96 & 110 & 13 & 46 & 55 & 49 \\
\hline $\mathrm{Ce}$ & 31 & 230 & 35 & 200 & 200 & 29 & 89 & 120 & 110 \\
\hline $\mathrm{Nd}$ & 13 & 120 & 23 & 110 & 94 & 18 & 44 & 72 & 55 \\
\hline $\mathrm{Sm}$ & 5 & 21 & 5.2 & 20 & 15 & 4.8 & 8.4 & 15 & 13 \\
\hline $\mathrm{Eu}$ & 1.8 & 3.2 & 1.8 & 3.1 & 2.7 & 1.8 & 1.5 & 3.3 & 3.1 \\
\hline $\mathrm{Tb}$ & 1.1 & 3.2 & 0.84 & 2.8 & 2 & 0.83 & 1.4 & 2.5 & 2.3 \\
\hline $\mathrm{Yb}$ & 3.3 & 9.2 & 3.3 & 8.8 & 8.2 & 3.5 & 6.6 & 11 & 9.1 \\
\hline $\mathrm{Lu}$ & 0.45 & 1.2 & 0.45 & 1.1 & 1.1 & 0.48 & 0.85 & 1.4 & 1.3 \\
\hline Hf & 4.4 & 22 & 4.7 & 20 & 16 & 5.1 & 6 & 12 & 12 \\
\hline $\mathrm{Ta}$ & 0.97 & 8.4 & 1.1 & 7.6 & 9.1 & 1 & 2.8 & 3.8 & 3.5 \\
\hline Th & 1.2 & 13 & 1.6 & 12 & 11 & 1.3 & 9.4 & 6.1 & 5.5 \\
\hline $\mathrm{U}$ & $<0.6$ & 3.3 & $<0.6$ & 2.7 & 3 & $<0.6$ & 2.3 & 1.6 & 1.1 \\
\hline
\end{tabular}

Notes: $*=$ ash layer sampled at two depth intervals. $<50=$ below the detection limit.

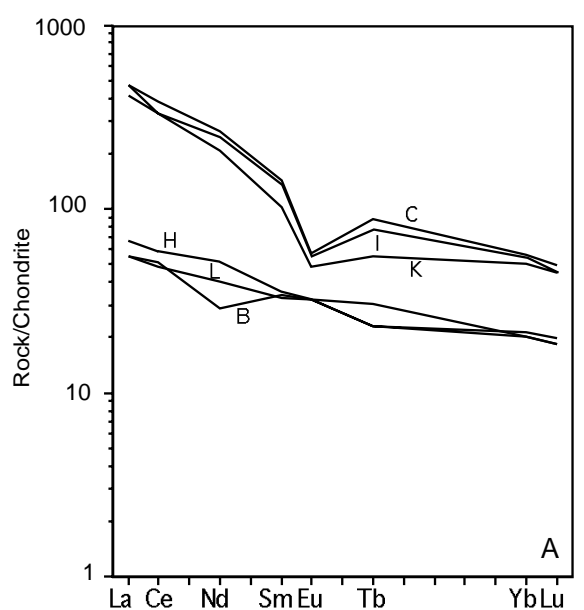

volcanic events associated with long-range ash transport are recorded as the occurrence of thin ash layers and ash zones. The lack of ash layers between isotope Stages 6 and 12 (128-478 ka) in Hole 919A may be related to a decrease in the volcanic/rifting activity because, by comparison, no ash fall has been recorded in Site 907 sediments between isotope Stages 8 and 15 (245-620 ka) (Lacasse et al., in press). Seasonal sea ice is known to have extended into the Irminger Basin as far as Site 919, during the LGM, 18 ka (fig. 18 in Lacasse et al., 1996) and, therefore, could have partially prevented the deposition of ash fall on the ocean floor in this region during glacial condition. Following ice-rafting, it has contributed to the widespread dispersal of tephra such as the ash Zone 1 at Site 919 (Fig. 2).

The discrete ash fall layers at Site 919 were derived from large explosive eruptions in Iceland and dispersal of tephra by easterly or northeasterly winds. The distance from source and grain size of the tephra suggest that the eruption columns likely reached the tropopause and stratosphere in order to allow long-range transport of glass shards. At present the only easterly winds prevailing in the stratosphere are reported to occur during midsummer above $30 \mathrm{~km}$ elevation (Reiter, 1971). Very little is known concerning a possible shift in the stratospheric winds direction associated with long term climate fluctuations (i.e., glacial-interglacial oscillations). Unpublished results of Atmospheric General Circulation Model (AGCM) simulation of Kutzbach and Guetter indicate limited change in subpolar and polar region in the Northern Hemisphere with slightly stronger stratospheric winds during the LGM (J. Merrill, pers. comm., 1996).

Among the few tephra falls recorded at Site 919, two were found to occur within $30 \mathrm{~cm}$ (Layers B and C in Hole 919A) and $70 \mathrm{~cm}$ (Layers H and I in Hole 919B) depth interval, at about 10-11 mbsf (Table 1). The two volcanic eruptions that have generated these tephra occurred over an interval of a few hundred years according to the sedimentation rate $(\sim 12 \mathrm{~cm} / \mathrm{k} . \mathrm{y}$.). The lowermost layer (Layer C in Hole 919A and Layer I in Hole 919B) is composed of rhyolitic glass shards (>90\%) and correlated to the ash Zone 2 in the North Atlantic (Fig. 6). In contrast, the uppermost layer (Layer B in Hole 919A and Layer H in Hole 919B) shows a mixed composition with variable amounts of basaltic and rhyolitic glass shards (Table 1), with a rhyolitic glass composition similar to that of ash Zone 2 (Fig. 6). This indicates a common origin from the silicic central volcano Tindfjallajökull in southern Iceland, also the source of the Thórsmörk Ignimbrite (Jørgensen, 1980, 1981; Sigurdsson, 1982; Lacasse et al., 1996). 
These two tephra are bimodal in composition showing two different compositional fields for the basaltic glass shards (Table 1; Fig. 5). This raises a question about unique or multiple sources for the mafic components. Approximately $4 \%$ of the juvenile products of the Thórsmörk Ignimbrite are mafic glasses, ranging from basaltic through intermediate hybrids to dacite (Jørgensen, 1981). No mafic glass chemistry from Thórsmörk has been reported in the literature and therefore no comparison can be made with the two marine tephra layers. Furthermore, Figure 5 shows that other volcanic centers in the Eastern Volcanic Zone in Iceland, located near Tindfjallajökull volcano, may have erupted basaltic and intermediate tephra during the same period.

Two mixed ash bands in the Dye 3 ice core in southern Greenland (Fig. 1), within a time interval of about $400 \mathrm{yr}$, were reported by Ram and Gayley (1991). From the major element concentration of its rhyolitic glass and its stratigraphic position, the lower band was correlated to the marine ash Zone 2 (Ram and Gayley, 1991; Grönvold et al., 1995). The ice record indicates, however, an age of about $70 \mathrm{ka}$, older than the 55-57.5 ka age inferred from the marine record (Smythe et al., 1985; Lacasse et al., 1996). This discrepancy might result from the difficulty in dating the Wisconsinian ice as a result of ice deformation (Dansgaard et al., 1985).

Recent dating of ash Zone 2 in the GRIP ice core indicates an age of $52 \mathrm{ka}$ for this tephra (Grönvold et al., 1995). No glass chemistry for the upper most ash band in the Dye 3 core has been published, and therefore no correlation with other known marine record has been proposed. However, we suggest that the rhyolitic glass shards from the two ash bands found in the Dye 3 ice core and the two discrete tephra layers at about 10-11 mbsf at Site 919 may have been produced by two large explosive eruptions from the silicic Tindfjallajökull volcano in southern Iceland. Their stratigraphic position indicates that the two events took place within a few hundred year interval (around $400 \mathrm{yr}$ ), when glaciation was initiated during isotope Stages 3 and 4 .

\section{CONCLUSIONS}

Major and trace element chemistry of ash layers of Site 919 indicates that Iceland was the only volcanic source supplying tephra to the Irminger Basin during the Pliocene-Pleistocene. Compositionally bimodal (basaltic and rhyolitic) and basaltic ash layers also can be uniquely correlated to specific volcanic centers on Iceland. All the homogeneous basaltic tephra exhibit glass compositions incompatible with an origin from the submarine part of the Mid-Atlantic Ridge (i.e., the Reykjanes Ridge).

A mixed ash zone occurs as dispersed glass shards over a depth interval of several tens of centimeters within the uppermost $50 \mathrm{~cm}$ of sediment. It is correlated to ash Zone 1, a chronostratigraphic marker ${ }^{14} \mathrm{C}$ dated at $11,000-11,100 \mathrm{yr}$ BP in marine sediment in the North Atlantic (Bard et al., 1994), and 11,980 $\pm 60 \mathrm{yr}$ BP in a Greenland ice core (Grönvold et al., 1995). The rhyolitic tephra originated from a large explosive eruption in the Katla caldera in southern Iceland during the Younger Dryas climatic transition (Lacasse et al., 1995). Chemical composition of basaltic glass shards shows multiple sources located in southern Iceland: Veidivötn, Grímsvötn, and Katla (Mangerud et al., 1984; Kvamme et al., 1989).

Based on their rhyolitic glass composition, two discrete and bimodal ash layers, at about 10-11 mbsf, were correlated to ash Zone 2, a chronostratigraphic marker $\delta^{18} \mathrm{O}$ dated at $55-57.5 \mathrm{ka}$ in marine sediment in the North Atlantic (Smythe et al., 1985; Lacasse et al., 1996) and at $52 \mathrm{ka}$ in a Greenland ice core (Grönvold et al., 1995). The rhyolitic tephra are interpreted to be derived from two large explosive eruptions occurring at a few hundred years interval, from the Tindfjallajökull volcano, a silicic volcanic center in southern Iceland. Uncertainty remains concerning the source of the basaltic components, which were derived either from Tindfjallajökull itself or other volcanoes on the Eastern Volcanic Zone in Iceland. These two tephra ho- rizon in Site 919 sediment are thought to be the same found between 1949 and 1950 m below the snow surface in the Dye 3 ice core in southern Greenland, approximately $400 \mathrm{~km}$ northwest of Site 919 (Ram and Gayley, 1991).

The sedimentological and grain-size characteristics of the tephra layers are compatible with ash fall from large explosive eruptions in Iceland. Assuming unchanged atmospheric circulation during the Pliocene-Pleistocene, the tephra were transported by easterly stratospheric winds occurring at about $30 \mathrm{~km}$ elevation during midsummer, followed by fallout both on southern Greenland and in the Irminger Basin.

\section{ACKNOWLEDGMENTS}

We thank Joseph Devine for assistance with microprobe analyses at the Geological Sciences Department of Brown University. This research benefited greatly from information provided by Ben Flower ( $\delta^{18} \mathrm{O}$ stratigraphy). The authors express their sincere thanks to Karl Grönvold, Katharine Cashman, and B. Wathen (ODP) for their constructive reviews. Lacasse's work was supported by a grant from JOI/ USSAC and is a part of a Ph.D. dissertation.

\section{REFERENCES}

Anders, E., and Grevesse, N., 1989. Abundances of the elements: meteoritic and solar. Geochim. Cosmochim. Acta, 53:197-214.

Bard, E., Arnold, M., Mangerud, J., Paterne, M., Labeyrie, L., Duprat, J., Mélières, M.-A., Sønstegaard, E., and Duplessy, J.-C., 1994. The North Atlantic atmosphere-sea surface ${ }^{14} \mathrm{C}$ gradient during the Younger Dryas climatic event. Earth Planet. Sci. Lett., 126:275-287.

Cande, S.C., and Kent, D.V., 1992. A new geomagnetic polarity time scale for the Late Cretaceous and Cenozoic. J. Geophys. Res., 97:1391713951.

Craig, R.A., 1965. The Upper Atmosphere: Meteorology and Physics: New York (Academic Press).

Dansgaard, W., Clausen, H.B., Gundestrup, N., Johnsen, S.J., and Rygner, C., 1985. Dating and climatic interpretation of two deep Greenland ice cores. Am. Geophys. Union Monogr., 33:71-76.

Fiacco, R.J., 1991. Microparticles as a paleovolcanic indicator in the 1989 GISP2 firn and ice core [M.S. thesis]. Univ. of New Hampshire.

Fiacco, R.J., Palais, J.M., Germani, M.S., Zielinski, G.A., and Mayewski, P.A., 1993. Characteristics and possible source of a 1479 A.D. volcanic ash layer in a Greenland ice core. Quat. Res., 39:267-273.

Folk, R.L., 1974. Petrology of Sedimentary Rocks: Austin, TX (Hemphill Publ.).

Grönvold, K., Oskarsson, N., Johnsen, S.J., Clausen, H.B., Hammer, C.U., Bond, G., and Bard, E., 1995. Ash layers from Iceland in the Greenland GRIP ice core correlated with oceanic and land sediments. Earth Planet. Sci. Lett., 135:149-155.

Hammer, C.U., 1977. Past volcanism revealed by Greenland ice sheet impurities. Nature, 270:482-486.

, 1984. Traces of Icelandic eruptions in the Greenland ice sheet. Jökull, 34:51-65.

Imbrie, J., Hays, J.D., Martinson, D.G., McIntyre, A., Mix, A.C., Morley, J.J., Pisias, N.G., Prell, W.L., and Shackleton, N.J., 1984. The orbital theory of Pleistocene climate: support from a revised chronology of the marine $\delta^{18} \mathrm{O}$ record. In Berger, A., Imbrie, J., Hays, J., Kukla, G., and Saltzman, B. (Eds.), Milankovitch and Climate (Pt. 1), NATO ASI Ser. C, Math Phys. Sci., 126: Dordrecht (D. Reidel), 269-305.

Imsland, P., 1984. Petrology, mineralogy and evolution of the Jan Mayen magma system. Soc. Scientar. Island., 43.

INQUA Inter-Congress Committee on Tephrochronology, 1990. Standardisation of the chemical analysis of tephra deposits. Field Conference and Workshop on Tephrochronology: Abstracts, Mammoth Hot Springs, Yellowstone National Park, 55-60.

Jakobsson, S.P., 1979a. Outline of the petrology of Iceland. Jokull, 29:57-73. , 1979b. Petrology of Recent basalts of the Eastern Volcanic Zone, Iceland. Act. Naturalia Isl., 26.

Johannessen, O.M., 1986. Brief overview of the physical oceanography. In Hurdle, B.G. (Ed.), The Nordic Seas: New York (Springer Verlag), 103127. 
Jørgensen, K., 1980. The eruption of the Thórsmörk ignimbrite, south Iceland: the structure of the magma chamber deduced from the eruption products. Nord. Volcanol. Inst., Rep., 8103.

1981. The Thórsmörk ignimbrite: a review. In Self, S., and Sparks, R.S.J. (Eds.), Tephra Studies: Dordrecht (Reidel), 347-354.

Kellogg, T.B., 1973. Late Pleistocene climatic record in Norwegian and Greenland Sea deep-sea cores [Ph.D. thesis]. Columbia Univ., New York. 1975. Late Quaternary climatic changes in the Norwegian and Greenland seas. In Bowling, S.A., and Weller, G. (Eds.), Climate of the Arctic. Geophys. Inst., Univ. Alaska, Fairbanks, 3-36.

- 1980. Paleoclimatology and paleo-oceanography of the Norwegian and Greenland seas: glacial-interglacial contrasts. Boreas, 9:115137.

Kvamme, T., Mangerud, J., Furnes, H., Ruddiman, W.F., 1989. Geochemistry of Pleistocene ash zones in cores from the North Atlantic. Norsk Geol. Tidsk., 69:251-272.

Lacasse, C., Paterne, M., Werner, R., Wallrabe-Adams, H.J., Sigurdsson, H., Carey, S., and Pinte, G., in press. Geochemistry and origin of Pliocene and Pleistocene ash layers from the Iceland Plateau, Site 907, Leg 151. In Thiede, J., Myhre, A.M., Firth, J.V., Johnson, G.L., and Ruddiman, W.F. (Eds.), Proc. ODP, Sci. Results, 151: College Station, TX (Ocean Drilling Program).

Lacasse, C., Sigurdsson, H., Carey, S., Paterne, M., and Guichard, F., 1996. North Atlantic deep-sea sedimentation of late Quaternary tephra from the Iceland hotspot. Mar. Geol., 129:207-235.

Lacasse, C., Sigurdsson, H., Jóhannesson, H., Peterne, M., and Carey, C., 1995. The source of ash zone I in the North Atlantic. Bull. Volcanol., 57$1: 18-32$.

Lackschewitz, K.S., and Wallrabe-Adams, H.-J., 1991. Composition and origin of sediments on the mid-oceanic Kolbeinsey Ridge, north of Iceland. Mar. Geol., 101:71-82.

Lackschewitz, K.S., Wallrabe-Adams, H.-J., and Garbe-Schönberg, D., 1994. Geochemistry of surface sediments from the mid-oceanic Kolbeinsey Ridge, north of Iceland. Mar. Geol., 121:105-119.

Larsen, G., 1981. Tephrochronology by microprobe glass analysis. In Self, S., and Sparks, R.S.J. (Eds.), Tephra Studies: Dordrecht (Reidel Publ.), 95-102.

Larsen, H.C., 1990. The East Greenland Shelf. In Grantz, A., Johnson, G.L., and Sweeney, J.F. (Eds.), The Arctic Ocean Region: Boulder, CO (Geol. Soc. Am.), Geol. of North Am. Ser., L:185-210.

Larsen, H.C., Saunders, A.D., Clift, P.D., Beget, J., Wei, W., Spezzaferri, S., and the ODP Leg 152 Scientific Party, 1994. Seven million years of glaciation in Greenland. Science, 264:952-955.

Le Bas, M.J., Le Maitre, R.W., Streckeisen, A., and Zanettin, B., 1986. A chemical classification of volcanic rocks based on the total alkali-silica diagram. J. Petrol., 27:745-750.

Luyendyk, B.P., Cann, J.R., et al., 1979. Init. Repts. DSDP, 49: Washington (U.S. Govt. Printing Office).

Maaløe, S., Sorensen, I., and Hertogen, J., 1986. The trachybasaltic suite of Jan Mayen. J. Petrol., 27:439-466.

Mangerud, J., Lie, S.E., Furnes, H., Kristiansen, I.L., and Lømø, L., 1984. A Younger Dryas ash bed in western Norway, and its possible correlations with tephras in cores from the Norwegian Sea and the North Atlantic. Quat. Res., 21:85-104.

Meyer, P.S., Sigurdsson, H., and Schilling, J.-G., 1985. Petrological and geochemical variations along Iceland's neovolcanic zones. J. Geophys. Res., 90:10043-10072.

Nielsen, C.H., and Sigurdsson, H., 1981. Quantitative methods for electron microprobe analysis of sodium in natural and synthetic glasses. Am. Mineral., 66:547-552.

O’Nions, R.K., Fridleifsson, I.B., and Jakobsson, S.P., 1973. Strontium isotopes and rare earth elements in basalts from the Heimaey and Surtsey volcanic eruptions. Nature, 243:213-214

O'Nions, R.K., and Grönvold, K., 1973. Petrogenetic relationships of acid and basic rocks in Iceland: Sr isotopes and rare earth elements in late postglacial volcanics. Earth Planet. Sci. Lett., 19:397-409.

O’Nions, R.K., Pankhurst, R.J., and Grönvold, K., 1976. Nature and development of basalt magma sources beneath Iceland and the Reykjanes Ridge. J. Petrol., 17:315-338.

Oskarsson, N., Sigvaldason, G.E., and Steinthorsson, S., 1982. A dynamic model of rift zone petrogenesis and the regional petrology of Iceland. $J$. Petrol., 23:28-74.
Palais, J.M., Germani, M.S., and Zielinski, G.A., 1992. Inter-hemispheric transport of volcanic ash from a 1259 A.D. volcanic eruption to the Greenland and Antarctic ice sheets. Geophys. Res. Lett., 19:801-804.

Palais, J.M., Kirchner, S., and Delmas, R.J., 1990. Identification of some global volcanic horizons by major element analysis of fine ash in Antarctic ice. Ann. Glaciol., 14:216-220.

Palais, J.M., Taylor, K., Mayewski, P.A., and Grootes, P., 1991. Volcanic ash from the 1362 A.D. Oræfajökull eruption (Iceland) in the Greenland ice sheet. Geophys. Res. Lett., 18:1241-1244.

Palmen, E.H., 1969. Atmospheric Circulation Systems: their Structure and Physical Interpretation: New York (Academic Press).

Ram, M., and Gayley, R.I., 1991. Long-range transport of volcanic ash to the Greenland ice sheet. Nature, 349:401-404.

Reiter, E.R., 1971. Atmospheric Transport Processes (Pt. 2): Chemical Tracers. U.S. Atomic Energy Comm.

Ruddiman, W.F., and Glover, L.K., 1972. Vertical mixing of ice-rafted volcanic ash in North Atlantic sediments. Geol. Soc. Am. Bull., 83:2817-2835.

Ruddiman, W.F., and McIntyre, A., 1973. Time-transgressive deglacial retreat of polar waters from the North Atlantic. Quat. Res., 3:117-130. , 1976. Northeast Atlantic Paleoclimatic changes over the past 600,000 Years. In Cline, R.M., and Hays, J.D. (Eds.), Investigation of Late Quaternary Paleoceanography and Paleoclimatology. Mem.Geol. Soc. Am., 145:11-145.

Sejrup, H.-P., Sjøholm, J., Furnes, H., Beyer, I., Eide, L., Jansen, E., and Mangerud, J., 1989. Quaternary tephrachronology on the Iceland Plateau, north of Iceland. J. Quat. Sci., 4:109-114.

Shipboard Scientific Party, 1994a. Site 919. In Larsen, H.C., Saunders, A.D., Clift, P.D., et al., Proc. ODP, Init. Repts., 152: College Station, TX (Ocean Drilling Program), 257-277.

1994b. Summary and principal results. In Larsen, H.C., Saunders, A.D., Clift, P.D., et al., Proc. ODP, Init. Repts., 152: College Station, TX (Ocean Drilling Program), 279-292.

Sigurdsson, H., 1971. Feldspar relations in Icelandic alkalic rhyolites. Mineral. Mag., 38:503-510.

, 1981. First-order major element variation in basalt glasses from the Mid-Atlantic Ridge: $29^{\circ} \mathrm{N}$ to $73^{\circ} \mathrm{N}$. J. Geophys. Res., 86:9483-9502. 1982. Ubreidsla íslenskra gjóskulaga á botni Atlantshafs. In Eldur er í Nordri, Sögufélag, Reykjavík, 119-127.

Sigurdsson, H., and Loebner, B., 1981. Deep-sea record of Cenozoic explosive volcanism in the North Atlantic. In Self, S., and Sparks, R.S.J. (Eds.), Tephra Studies: Dordrecht (Reidel), 289-316.

Sjøholm J., Sejrup H.P., and Furnes, H., 1991. Quaternary volcanic ash zones on the Iceland Plateau, southern Norwegian Sea. J. Quat. Sci., 6:159173.

Smythe, F.W., Ruddiman, W.F., and Lumslen, D.N., 1985. Ice-rafted evidence of long-term North Atlantic circulation. Mar. Geol., 64:131-141.

Sparks, R.S.J., Wilson, L., and Sigurdsson, H., 1981. The pyroclastic deposits of the 1875 eruption of Askja, Iceland. Philos. Trans. R. Soc. London A, 299:241-273.

Thompson, R.N., and MacKenzie, W.S., 1967. Feldspar-liquid equilibria in peralkali liquids: an experimental study. Am. J. Sci., 265:714.

Thórarinsson, S., 1967. The eruption of Hekla 1947-1948. Soc. Scient. Island., I.

Varet, J., and Metrich, N., 1979. Ash layers interlayered with the sediments of Holes 407 and 408, IPOD Leg 49. In Luyendyk, B.P., Cann, J.R., et al., Init. Repts. DSDP, 49: Washington (U.S. Govt. Printing Office), 437441.

Zielinski, G.A., Mayewski, P.A., Meeker, L.D., Whitlow, S., Twickler, M.S., Morrison, M., Meese, D.A., Gow, A.J., and Alley, R.B., 1994. Record of volcanism since 7000 B.C. from the GISP2 Greenland ice core and implications for the volcano-climate system. Science, 264:948-951.

Zielinski, G.A., Mayewski, P.A., Meeker, L.D., Whitlow, S., and Twickler, M.S., 1996. An 110,000-year record of explosive volcanism from the GISP2 (Greenland) ice core. Quat. Res., 45: 109-118.

Date of initial receipt: 30 October 1995

Date of acceptance: 21 May 1996 Ms 152SR-205 